

\title{
Anthraco-typology as a key approach to past firewood exploitation and woodland management reconstructions. Dendrological reference dataset modelling with dendro-anthracological tools
}

Alexa Dufraisse, Sylvie Coubray, Olivier Girardclos, Noémie Nocus, Michel Lemoine, Jean-Luc Dupouey, Dominique Marguerie

\section{To cite this version:}

Alexa Dufraisse, Sylvie Coubray, Olivier Girardclos, Noémie Nocus, Michel Lemoine, et al.. Anthracotypology as a key approach to past firewood exploitation and woodland management reconstructions. Dendrological reference dataset modelling with dendro-anthracological tools. Quaternary International, 2018, 463 (part B), pp.232-249. 10.1016/j.quaint.2017.03.065 . hal-01637751

\section{HAL Id: hal-01637751 \\ https://hal.science/hal-01637751}

Submitted on 29 Mar 2018

HAL is a multi-disciplinary open access archive for the deposit and dissemination of scientific research documents, whether they are published or not. The documents may come from teaching and research institutions in France or abroad, or from public or private research centers.
L'archive ouverte pluridisciplinaire $\mathbf{H A L}$, est destinée au dépôt et à la diffusion de documents scientifiques de niveau recherche, publiés ou non, émanant des établissements d'enseignement et de recherche français ou étrangers, des laboratoires publics ou privés.

\section{(ㄷ)(1)(2)}

Distributed under a Creative Commons Attribution - ShareAlikel 4.0 International 
Anthraco-typology as a key approach to past firewood exploitation and woodland management reconstructions. Dendrological reference dataset modelling with dendroanthracological tools

Alexa Dufraisse $^{1 *}$, Sylvie Coubray ${ }^{1,3}$, Olivier Girardclos ${ }^{2}$, Noémie Nocus ${ }^{1}$, Michel Lemoine ${ }^{1}$, Jean-Luc Dupouey ${ }^{4}$, Dominique Marguerie ${ }^{5}$

1 Sorbonne Universités, CNRS, Muséum national d'Histoire naturelle, UMR 7209, Archéozoologie, Archéobotanique: sociétés, pratiques et environnements, CP56, 55 rue Buffon, 75005 Paris, France

${ }^{2}$ CNRS, University of Bourgogne-Franche-Comté, UMR 6249, Chrono-Environnement, 16 route de Gray 25030 Besançon cedex

${ }^{3}$ INRAP, Centre Île-de-France, 41 rue Delizy 93690 Pantin cedex

${ }^{4}$ INRA, UMR EEF, Ecologie et Ecophysiologie forestières, 54280 Champenoux

${ }^{5}$ CNRS, UMR 6553 ECOBIO, University of Rennes 1, Beaulieu, 35042 Rennes cedex

*Corresponding author: alexa.dufraisse@mnhn.fr

\section{Abstract}

Charcoal analysis aims to study different aspects of forest management, technoeconomical choices and their specific impact on past landscapes, as well as the impact of climatic events. However, at the present time, charcoal analysis is generally limited to the study of a list of taxa and their relative frequency, as the methods usually employed in dendrochronology to characterize past woodland, based on long tree-ring series, are not suitable for anthracological material. Today, the new challenge for charcoal analysis is thus to develop adapted dendrological tools. In this context, the aim of the ANR DENDRAC project "Development of dendrometrical tools applied to anthracology: study of the interactions between Man, resources and environments" was to characterize modern-day wood stands in accordance with historical woodland practices and convert dendroecological 
data into parameters adapted to charcoal analysis. The purpose of this study is to define the dendrological features with the help of the anthracological tools without explaining the observed differences between the sampled stands (given the stational variability, age and regeneration modes). The first step consisted in creating dendro-anthracological tools based on morpho-anatomical criteria that help to characterize growth, distinguish heartwood from sapwood and evaluate charcoal-pith distance. The second step involves characterizing three modern-day wood stands (coppice under standard, high forest and young stand formed by a mixture of seeded and coppice trees), defined by their structure, stand density and regeneration modes, using dendrological data measured on fresh wood material and modelled into anthracological data with the dendro-anthracological tools. In this way, anthracological types were defined for each wood stand, forming anthraco-typological models, which area useful for the interpretation of archaeological charcoal assemblages. Finally, an anthracological key is proposed to sort archaeological charcoal fragments in anthraco-groups before data processing.

Keywords : firewood management; dendro-anthracological tools; anthraco-typology; anthraco-group; deciduous oak

\section{Introduction}

1.1. Anthracology and past woodland reconstruction

The questions raised by relationships between people and the environment in time and space can be explored by archaeological, ethnographic or environmental approaches. The management of the environment for (plant or animal) food strategies reflects, to some extent, human societies and their organization, their lifestyles, their perception of the environment and the landscape in which they operate.

Forest exploitation in order to produce wood material for multiple needs, is perceptible at different scales: the tree, the woodland and the landscape (Michon, 2005, 2015); Humans 
"domesticate" the tree by modifying its architecture, its growth cycle, its production and its reproductive functions. This domestication also concerns the forest ecosystem transformed by practices. Wood stands are shaped by and for societies living in them as a result of the installation of fields, herds and villages in forest areas. Variable spatial patterns results from this articulation between forest and agriculture, the landscapes.

Firewood management contributes to this "domestication". It is part of a complex system closely related to social organization, technical and economic systems, and the environment itself (Chabal, 1997; Picornell Gelabert, 2011; Dufraisse, 2012; Salavert and Dufraisse, 2014). Thus, archaeological charcoal fragments, residues of firewood selected and transported by humans, are valuable ecofacts reflecting use, techniques and woodland management, and are themselves conditioned by environmental resources (available wood resources, i.e. biodiversity and biomass).

In forest science, the criteria characterizing wood stands are the composition (dominant and secondary species), stand density (number of stems per hectare), structure (distribution of age and diameter classes of trees) and modes of regeneration (seeded or vegetative renewal) (Rondeux, 1999). The methods usually employed in dendrochronology to extract this information are not suited to anthracological material. In dendrochronology, samples usually come from timber wood and generally from trunks and/or branches or roots, the wood is not charred, the methods are based on statistical tools that require at least 50 consecutive rings and it is possible to individualize the signals (study of distinct elements). In anthracology, fragments derive from trunks and/or branches or roots, the wood is charred, fragmented and incomplete as it is partially reduced to ashes, the fragments present on average less than five rings and result from the exploitation of many indistinguishable individuals (Dufraisse, 2006; Marguerie, 2011). Consequently, in the absence of adequate tools, charcoal analysis is most often limited to the study of a list of taxa and their relative frequency without exploiting the information contained in the wood anatomy. The identification of the morphological characteristics of harvested firewood (part of the tree, age, 

wood exploitation.

shape, etc.) still raises methodological problems even though it is a fundamental element for characterizing firewood exploitation techniques and reconstructing the populational and environmental parameters of wood stands.

In order to address this need to learn more about forest exploitation and practices, the ANR DENDRAC project "Development of dendrometrical tools used in anthracology: study of the interactions between Man, resources and environments" aims to convert dendroecological data measured on fresh wood material from modern-day oak wood stands corresponding to different types of historical woodland practices - into parameters adapted to charcoal analysis, using a method similar to that developed by A. Billamboz, termed dendrotypology (Billamboz, 2011, 2014). His method consists in establishing a typological classification of tree-ring series according to their growth patterns. The application of a similar method in anthracology involves associating the identification of the taxa with the examination of dendrological and anatomical parameters; a concept that leads to the notion of dendro-anthracology (Marguerie et al., 2010). Deciduous European oak (Quercus petraea/robur) was chosen for its abundance in temperate forests, its anatomy with clearly identifiable growth rings and its representativity in anthracological spectra.

In the present study, we postulate that the characteristics of an assemblage of treerings can be exploited, without taking into account tree-ring series in terms of time series like in dendrochronology. The first step consisted in developing dendro-anthracological tools based on morpho-anatomical features. The second step was to convert dendroecological data to form an anthraco-typological grid, which could then be used as a key approach for the interpretation of archaeological charcoal assemblages. This approach was applied to three modern-day wood stands: a coppice under standard, a high forest and a young stand formed by a mixture of seeded and coppice trees. Analysis was conducted at different levels: 
1.2. The dendro-anthracological tools

114

Growth rate is a widely used dendro-anthracological parameter, but the successive tree-rings width series of each charcoal fragment must be localized as precisely as possible on the stem cross-section. In that aim, different dendro-anthracological tools are proposed in order i) to distinguish sapwood from heartwood which provides information about the minimal age of the wood (heartwood formation i.e. duraminisation starts when deciduous oak is around 25 years old) ii) to localize the tree-ring series in respect to the center of the stem, iii) to model dendroecological data from modern wood stands into dendro-anthracological parameters adapted to charcoal analysis.

\subsubsection{The Heartwood-Sapwood discriminating tool}

In some species the coloration of heartwood due to the deposition of lignins and polyphenols makes heartwood recognizable, but the charcoalification process that occurs during carbonization obliterates the colour difference, making this feature unusable in anthracology. Fortunately, in some Angiospermae, such as deciduous European oak (Quercus petraea/robur), the formation of tyloses (cellulose walls expansions) in earlywood vessels is an important feature of the changeover of sapwood to heartwood. However, tylosis formation also occurs in sapwood and increases with the formation of heartwood, from $0 \%$ of tyloses in the cambial region and close to $100 \%$ in the heartwood. Thus, we quantify the number of vessels sealed by tylosis in order to establish discriminating thresholds between sapwood and heartwood (Fig.1a) (Dufraisse et al., 2016). Trunks and branches of ten deciduous oak trees from 15 to 60 years old were sampled in three stations in order to evaluate the number of earlywood vessels with tylosis in sapwood and heartwood. For an application to archaeological charcoal (tyloses are preserved until $800^{\circ} \mathrm{C}$ ), at least one tree ring and 15 vessels must be counted. The best strategy is to count 50 vessels spread over $3-$ 4 tree rings. Thresholds of less than $65 \%$ for sapwood and up to $85 \%$ for heartwood are 
significant. Besides the discrimination of sapwood and heartwood, the process of heartwood

142 formation starts when deciduous oak is about 25 years old. The absence of heartwood is 143 thus an indication of the exploitation of young wood (trunks or branches).

2.2. The pith estimation tool

146

The pith estimation tool is used to measure the distance between the charcoal fragment and the center of the stem (or the missing pith), named the "charcoal-pith distance". This measurement is taken with the trigonometric pith estimation tool based on measurements of the angle and the distance between two ligneous rays (Fig. 1 b) (Dufraisse and Garcia Martinez, 2011; Paradis-Grenouillet et al., 2013). This tool was evaluated on fresh and carbonized oak wood discs with different angle values and distances between ligneous rays. This work enables us i) to propose exclusive criteria (angle $<2^{\circ}$ and distance $<2 \mathrm{~mm}$ ) for reducing the margin of error and improving results in archaeological applications, ii) to establish correction factors linked to the trigonometric tool itself (underestimation of distance values between 5 and $10 \mathrm{~cm}$ ) and the shrinkage which occurs during charcoalification, iii) to highlight that there are no reliable measurements for charcoal-pith distances beyond $12.5 \mathrm{~cm}$, i.e. diameter of $25 \mathrm{~cm}$ (Dufraisse and Garcia Martinez, 2011; Garcia Martinez and Dufraisse, 2012).

The values were ordered into diameter classes chosen to be compatible with standards used in dendrometrical plans by foresters (Gaudin, 1996; Deleuze et al., 2014). For Angiospermae the conventional wood cuts are $4 \mathrm{~cm}, 7 \mathrm{~cm}, 20 \mathrm{~cm}$, etc. Two cuts were added at 2 and $10 \mathrm{~cm}$ for more accurate interpretation of charcoal diameters, that is to say ]0-2] $\mathrm{cm}$, ]2-4] cm, ]4-7] cm, ]7-10] cm, ]10-20] and $>20 \mathrm{~cm}$. For Gymnospermae it is more appropriate to add a cut at $14 \mathrm{~cm}$, namely ]0-2] cm, ]2-4] cm, ]4-7] cm, ]7-10] cm, ]10-14] cm, ]14-20] $\mathrm{cm}$ and $>20 \mathrm{~cm}$. 
Burnt, wood undergoes both mass loss and charcoal fragmentation. Consequently,

171 the distribution of the charcoal-pith distances does not indicate unburnt wood diameter. Therefore, an Analysis Diameter model (ADmodel) was developed, based on the fact that a trunk is biologically considered to be a stack of cones (Fig. 1c) (Dufraisse, 2002; 2006; Dufraisse and Garcia Martinez, 2011). These cones are hollow and their thickness corresponds to the amplitude of the diameter classes. It is based on a calculation table that provides the respective distribution of these cones in terms of volume. The ADmodel breaks down unburnt wood diameter into an expected distribution of charcoal-pith distances. In return, the ADmodel is a helpful tool to interpret the distribution of charcoal-pith distances from a charcoal assemblage as unburnt wood diameter (UWD). However, this model does not reconstruct the initially quantity of burnt wood (Théry-Parisot et al., 2011). In the present study, only the ADmodel running into UWD decomposition is used. In the present study, each cone thickness was also characterized by a growth rate (cumulated tree-ring width divided by the number of tree rings) and its sapwood/heartwood affiliation.

\section{Material and Method}

186

The general analytical protocol consists in sampling modern-day oak woodlands corresponding to specific archaeological questions, removing logs from felled trees, cutting wood discs from logs and producing experimental charcoal assemblages (Fig. 2). Various kinds of datasets were produced: i) dendrometrical plans to characterize tree morphology and wood stands (composition, structure stand density, regeneration modes), ii)

192 dendrochronological data from wood discs, iii) anthracological data modelled with the 193 dendro-anthracological tools. 
With respect to historical woodland practices and to answer to specific archaeological issues such as the distinction branch/ trunk or coppice /high forest three "contrasted" deciduous oak stands managed by the National Forestry Office (ONF) in France were 200 chosen (Fig. 3). The first one is "Les Cagouillères ", located in the Vienne department, on a limestone plateau (altitude: $115 \mathrm{~m}$ ). It is in an old abandoned coppice woodland, about 62 202 years old, currently undergoing conversion to high forest. The second stand is "Bogny-sur203 Meuse" located in the Ardennes department. This is a coppice-under-standard growing on an acidic brown soil on schists, about 68 years old. The third stand is "Le Bois de l'Or", also located in the Ardennes department, near Bogny-sur-Meuse. This is a young stand, about 15 years old, formed by a mixture of even aged seeded and coppice trees (altitude: $350 \mathrm{~m}$ ).

In order to characterize the wood stands, forest inventory and dendrometric data were compiled. The basal area increment ( $\left.\mathrm{m}^{2} / \mathrm{ha}\right)$, stand density (number of stems per hectare), dominant height of the trees and the average square diameter were recorded distinguishing trees with diameters of more and less than $7.5 \mathrm{~cm}$ (table 1, Fig. 4).

The dendrological information for each tree, such as diameter, age, growth rate and radial growth trend, was defined at breast height on the field and from disc located at $1.30 \mathrm{~m}$ above ground, as is usual in dendroecology. However, the nature and representativeness of archaeological samples are different in dendroecology and anthracology. Consequently, for 
221 the conversion in anthracological data according to anthracological constraints, the

222 dendrological data were measured in the whole tree.

223 For the study of tree ring-climate relations in sessile oak, six is the number of optimal 224 trees to sample. For our purpose, and taking into account our archaeological questions, one 225 to five trees were felled and registered meter by meter, one dominant tree in the coppiceunder-standard at "Bogny-sur-Meuse", four dominant stems from distinct multi-stem trees at "Les Cagouillères" and five coppice shoots and five seeded trees at "Le Bois de l'Or".

For each tree, the total height, the height of the first large branch insertion on the stem and the height of the crown base were recorded as well as the diameter at breast height and regeneration modes. The set of tree morphology indicators is presented in table 1 and figure 4.

In order to estimate the relative proportion of trunk and branches for each tree and each stand, each tree was cut into logs of 1-metre-long including branches with a diameter of more than $4 \mathrm{~cm}$. A code was attributed to each log according to its position in the tree (height, number of branches, location in the branch). Length and circumference (at three points) of each log were measured to calculate the mean diameter and the volume. Branches with a diameter of less than $4 \mathrm{~cm}$ were packed into bundles according to two diameter classes; 0-2 cm and 2-4 cm. Each bundle was weighed. Sub-samples of wood were collected from each bundle to estimate the density of the wood and then to calculate the volume of each bundle.

In order to characterize each tree and then each wood stand at different levels (whole tree, and trunks and branches separately), one disc was removed from the extremity of each

246 log. In the present study, a subsample of the set of discs was taken by selecting discs at 247 different heights in the trunk and in the crown (23 discs for the four trees at "Les 
248 Cagouillères", 14 discs for the tree at "Bogny-sur-Meuse" and 77 discs for the 10 trees at "Le 249 Bois de l'Or" (Table 2a, 2b).

The tree-ring widths (discriminating earlywood and latewood) of each disc were measured to the nearest $0.01 \mathrm{~mm}$ using a LINTAB measurement device and associated TSAP software (Frank Rinn, Heidelberg, Germany) along 5 radii and averaged in order to reduce intra-tree variability.

Each tree-ring was then associated with a diameter class (calculated by the cumulated ring widths) and sapwood/heartwood. Thus, the proportion of sapwood and heartwood was characterized by averaging tree-ring numbers, tree-ring width and wood volume.

The usual dendro-anthracological parameters were first independently considered to obtain a "whole tree" estimation, and then the trunks and branches were separated. i) the distribution of growth-ring width, ii) the proportion of sapwood/heartwood, iii) the distribution of the decomposed unburnt wood diameters (UWD) were recorded.

\section{Results}

3.1. Dendrological features of the three wood stands (Fig. 4).

For the four sampled 62 years-old trees from "Les Cagouillères", the average diameter at breast height is $20.75 \mathrm{~cm}$. The average tree height is $17.7 \mathrm{~m}$ and $90,4 \%$ of the wood volume is from to the trunk. The low proportion of branches, with a diameter of less than $7 \mathrm{~cm}$, reflects an undeveloped crown (probably due to competition, a consequence of the abandonment of forest management). The dominant tree at "Bogny-sur-Meuse" is 68 years old with a diameter of $33 \mathrm{~cm}$ at breast height. The height is $20.3 \mathrm{~m}$ with a first large branch at $7.7 \mathrm{~m}$ and a more developed crown; branches represent $37.4 \%$ of the tree volume and can reach a diameter of $20 \mathrm{~cm}$. The trees at "Le Bois de l'Or" are 14 years old, their diameters average $10.21 \mathrm{~cm}, 8.6 \mathrm{~m}$ high, the trunk forms $78.38 \%$ of the volume and the diameter of branches less than $7 \mathrm{~cm}$ in diameter. Thus, the tree at "Bogny-sur-Meuse" is less 
slender than trees at "Les Cagouillères" and "Le Bois de l'Or" (see the height/diameter ratio, 277 table 1).

In the three sampled stands, trunk volume is always predominant and branches are poorly represented. The diameter $20-40 \mathrm{~cm}$ class is the best represented at "Bogny-surMeuse" whereas the $10-20 \mathrm{~cm}$ diameter class characterizes "Les Cagouillères". The main volume at "Le Bois de l'Or" is distributed between 7-10 diameter but a few trees reach $11 \mathrm{~cm}$ and thus belong to the $10-20 \mathrm{~cm}$ diameter class.

Radial growth rate and growth trends are different in each stand. Tree-ring widths average $1.23 \mathrm{~mm} /$ year at "Les Cagouillères" coppice, and the growth trend has been decreasing over the past 20 years due to strong competition between shoots, intra-tree and between stools. At "Bogny-sur-Meuse", growth-ring widths average $1.35 \mathrm{~mm} / \mathrm{year}$ and the growth trend has been decreasing slightly over the past 20 years. At "Le Bois de l'Or", growth-ring widths average $2.99 \mathrm{~mm} /$ year and are marked during the 1 to 10 first years by a steady increase in the coppice trees while seeded trees are characterized by narrowest rings than coppice from around the pith to 6-7 years, followed by an intensive growth period before a relatively sudden decrease (for more details, see Girardclos et al., 2016).

3.2. Simple dendro-anthracologial parameters

The distribution of the growth rates indicates differences at stand and tree levels (Fig. 5a). First, the difference in growth rate observed in $\S 3.1$ and only based on one disc localized at $1.30 \mathrm{~m}$ in the trunk, is conserved when the whole tree is taken into account, what is more realistic for anthracology. The growth rate at "Les Bois de l'Or" is the highest, followed by "Bogny-sur-Meuse" and "Les Cagouillères". For a same stand, we also note a significant difference between trunks and branches, the latter being characterized by a lower rate. Moreover, considering the different parts of the trunk (base, top, upper part in the crown), we note that the annual ring-width in the top of the bole is wider than in the lower 
part, and that the growth rate of the trunk localized in the crown is comparable with branches (Fig. 5b). However, this latter observation is less clear at "Le Bois de l'Or".

306

\subsubsection{Sapwood/heartwood}

The trees at "Le bois de l'Or", less than 15 years old, are characterized by the absence of heartwood, contrasting with "Bogny-sur-Meuse" and "Les Cagouillères" (Fig. 6). However, at "Les Cagouillères", heartwood formation is not yet initiated in branches. Conversely, the trunk and branches of the dominant tree at "Bogny-sur-Meuse » are characterized by heartwood and sapwood. The relative proportion of sapwood in trunk is less important at "Bogny-sur-Meuse" than at "Les Cagouillères". Likewise, the average number of sapwood tree-rings is less important at "Bogny-sur-Meuse". Nevertheless the average sapwood ring width is higher at "Bogny-sur-Meuse" reflecting more vigorous growth.

\subsubsection{Diameters}

The unburnt wood diameters (UWD) were decomposed with the ADmodel, according to the relative volume of each hollow cone composing the logs (Fig. 1c, 7).

The raw dendrological data indicate that there is little overlap between the diameters of branches and trunks. In fact, the low proportion of the trunk represented in the smallest diameter classes corresponds to the upper part of the trunk localized in the crown. Therefore, for each wood stand, the distribution of the decomposed UWD of branches is clearly distinct from the trunk. Besides, as the volume of branches is weak, the wood diameter pattern for whole trees does not show clear differences with that of the trunk.

\subsection{Combination of dendro-anthracological parameters}

$$
\text { 3.3.1. Decomposed UWD versus tree-ring width }
$$



wood stand. In dendroecology, growth trends are obtained by combining tree-ring width and cambial age. Given that i) the analysis of tree-ring patterns in segment of cambial age is considered relevant for studying forest dynamics and development (Haneca et al., 2005) ii) the distance of the charcoal from the pith can be estimated by the charcoal-pith tool, we combined tree-ring width with diameter classes. For the dendrological data, average tree-ring width was calculated for each cambial age. For the modelled anthracological data, average tree-ring width was calculated for each diameter class (Fig. 8).

The radial growth trends of the three wood stands are different and the modelled anthracological data correspond well to their dendrological characteristics. Even though the anthracological data are smoother because of the calculation of average ring width per diameter class, the radial growth trend is consisting of i) a strong increase in the radial growth of trees at "Le Bois de l'Or", reflecting a free juvenile growth, ii) the increase followed by a decrease at "Les Cagouillères" due to the high density of trees over a long period of time, iii) a slight decrease in the life of the tree at "Bogny-sur-Meuse" due to a managed coppice-under-standards. However, the differences observed between seeded and coppice trees at "Le Bois de l'Or" are no longer evident.

The branches at "Les Cagouillères" and "Bogny-sur-Meuse" are characterized by a lower growth rate than in the corresponding trunks (cf. § 3.2.1.) and by a downward growth. In contrast, the young seeded and coppice trunks at "Le Bois de l'Or", with diameters comparable to the branches, are characterized by a clearly higher growth rate and a more upward growth.

The radial growth rate of whole trees is lower in the first diameter classes than in the 356 trunk considered separately, as it includes the low growth rates of branches. Then, radial 357 growth increases from the boundary of the step between diameters of trunks and branches. 
The second combination aims to improve the interpretation of the distribution of the decomposed UWD by associating them with the presence or absence of heartwood, and the sapwood/heartwood ratio in each diameter class, as decomposed by the ADmodel (Fig. 9).

The distribution of heartwood/sapwood according to the diameter classes shows specific patterns for the different wood stands and possible exploitation modes (whole trees, trunks/branches separately).

At "Les Cagouillères", where branches are characterized by the absence of heartwood, the volume of the trunk is mainly distributed in the penultimate diameter class. The pattern of the whole trees is similar to that of the trunk, as branches only represent $9.58 \%$ of the volume. At "Bogny-sur-Meuse", the same pattern is observable but the main volume is represented in the last two diameter classes. However, regarding the whole tree, sapwood is better represented in the small diameter classes than at "Les Cagouillères", as branches account for $37.4 \%$ of the tree volume.

While the mature trees contain a central heartwood core (reflected by heartwood in the small diameter classes) and peripheral sapwood (reflected by sapwood in the largest 377 diameter classes), the absence of heartwood in trunks from "Le Bois de l'Or" and in branches

378 from "Les Cagouillères" is in agreement with young trunks and young branches respectively 379 (less than 25 years old for oak). They are characterized by small diameters with sapwood, and the absence of heartwood and of large diameters. The biggest branches of the tree from "Bogny-sur-Meuse", i.e. 10-20 cm, contain small amounts of heartwood, and traces of heartwood in the smaller classes. 
The third combination consists in combining tree-ring width with the decomposed

UWD and their respective affiliation to sapwood or heartwood (Fig. 10).

Globally, the pattern between whole trees and trunks from a same stand is similar. This is less obvious at "Bogny-sur-Meuse" where no disc from the upper part of the trunk without heartwood has yet been studied. However, we can expect the same pattern, characterized by sapwood and heartwood in all the diameter classes, and a lower average tree-ring width in sapwood corresponding to the external rings, which is coherent with the growth dynamic of trees (Fritts, 1976).

The exploitation of branches only is clearly distinct, with a low growth rate and the absence of heartwood in the case of young branches, as at "Les Cagouillères". If branches are a little older as at "Bogny-sur-Meuse", heartwood is absent in the largest classes of diameter. Lastly, the young vigorous seeded and coppice trees are characterized by a high growth rate in sapwood, while heartwood is absent.

\section{Discussion and application to charcoal assemblages}

The dendrological characteristics of each wood stand, discriminating branches, trunks and whole trees, were defined with the help of the dendro-anthracological tools. The dendroanthracological parameters (growth rate, heartwood/sapwood, diameters) were recorded independently of each other and then combined, forming anthraco-types (Fig. 11).

First of all, annual ring width was considered individually. Considering the whole tree and the trunk, ring width distribution is significantly different among stands. However, the distribution between seeded and coppice trees at "Le Bois de l'Or" is not significantly different. Likewise, the distribution between branches at "Les Cagouillères" and "Bogny-surMeuse" is not different. In each stand, branches are characterized by a lower growth rate than in the trunk. This observation is in agreement with the study of the variation of annual tree-ring width along the stem marked by a slight increase from the base to the top of the 
414 trunk and a strong decreasing in the upper part of the trunk (in the crown). These results are 415 similar to those of Dhôte et al. (1997), based on 82 Quercus petraea distributed in five 416 regions in France. Consequently, growth conditions are mainly recorded in the trunk and 417 branches should be avoided for palaeo-environmental reconstruction. This result fits with the method of D. Marguerie and J.-Y. Hunot (2007) whose the principle is to keep only tree-ring width measurements based on charcoal with large charcoal-pith distance.

At the scale of a charcoal assemblage, these data can be obtained by measuring each tree ring of each charcoal fragment and averaging them (per fragment). However, their interpretation remains problematic at this stage as they may come from different wood stands, trunks and/or branches, and it is not possible to distinguish them. In addition, it is difficult to interpret growth rate without contemporary, diachronic or modern-day reference standards.

The presence or the absence of heartwood and the proportion of sapwood/heartwood are good indicators of the maturity of the wood. In anthracology, sapwood and heartwood can be distinguished using the proportion of vessels sealed by tylosis (Dufraisse et al., 2016). Then each fragment can be affiliated to sapwood or heartwood. However, if although the absence of heartwood reflects the exploitation of young trees, it is difficult to interpret sapwood and heartwood proportions as external and internal sapwood are not differentiated. assemblage, charcoal diameters are obtained by measuring the charcoal-pith distance. The results indicate a diameter limit between branches and trunks for each wood stand, with almost no overlap, which is in agreement with the literature (Deleuze et al., 2014). However, 438 the exploitation of whole trees is difficult to distinguish from the exploitation of trunks on 439 account of the low branch volume. Consequently, if we hypothesize the exploitation of whole 440 trees, the proportion of branches will be inconspicuous and difficult to distinguish from the exploitation of trunks. In addition, as regards the exploitation of different wood stands, it is 
442 problematic to differentiate branches and young trunks solely on the basis of diameter 443 distribution

444

445 446

Thus, growth rate, heartwood/sapwood and wood diameters are three parameters that can be applied to charcoal assemblages. However, their use independently of each other is somewhat limited and sometimes difficult to interpret despite their information potential.

A first combination consisted in associating heartwood/sapwood and diameter parameters in order i) to differentiate the two kinds of sapwood: external sapwood in mature woods, and internal sapwood (absence of heartwood) in young woods ii) to improve the interpretation of the distribution of the decomposed UWD. Specific patterns were recorded according to wood stands and the exploitation modes (whole trees, trunks/branches separately). Young woods (trunk or branches) are characterized by absence of heartwood and small diameter classes, whereas mature wood is characterized by heartwood in small diameter classes and sapwood in the largest ones. In the scope of application to charcoal assemblages, this first combination yields four groups of charcoal fragments depending on their position in the wood: i) small diameter associated with sapwood corresponding to young woods, ii) small diameter associated with heartwood corresponding to the internal part of mature woods, iii) large diameter associated with heartwood corresponding to the middle part of mature woods and iv) large diameter associated with sapwood corresponding to the external part of mature woods.

The association of growth rates with the sapwood/heartwood ratio can provide information about the vigour of wood stands and tree morphology. For example, the proportion of sapwood is higher in trunks from "Les Cagouillères" (high forest) than in the trunk of the dominant tree at "Bogny-sur-Meuse" (coppice-under-standard). However, average sapwood ring-width and sapwood width are higher at "Bogny-sur-Meuse" than in "Les Cagouillères" (Fig. 7). This observation shows that i) for a same age (Bogny: 68 years 
470

471

472

473

474

475

476

477

478

479

480

481

482

483

484

485

486

487

488

489

490

491

492

493

494

495

old, Cagouillères: 62 years old), the most vigorous trees have a more extensive sapwood surface (Lebourgeois, 1999) ii) sapwood width is higher in coppice-under-standard than in high forest (Dhôte et al., 1997). Thus, the under-representation of sapwood in the trunk of the tree in "Bogny-sur-Meuse" is probably due to a larger tree diameter, $33 \mathrm{~cm}$ as opposed to $20.75 \mathrm{~cm}$.

The third combination consists in associating tree-ring width and diameters (distribution of the decomposed unburnt wood diameters). For an application to charcoal assemblage, each tree ring is associated with a charcoal-pith distance, then to a diameter class and finally an average tree-ring width is calculated for each diameter class. Radial growth trends appear to be preserved keeping with dendrological radial growth. An original pattern marked by a low growth rate along the smallest diameter classes followed by a higher rate in the largest diameter classes may be a characteristic of the exploitation of whole trees. However, as it is often the case in dendroecology, one pattern may correspond to several scenarios. Here for example, a partial clearing of the wood stand could lead to a comparable growth trend. Thus interpretations have to be associated with the results established by other disciplines. In addition, an initial distinction between young trunks (coppice) and young branches becomes possible as their growth rate and growth trend differ (high rate and upward trend for coppice, low rate and downward trend for branches). However, no further distinction is visible between coppice and seeded trees at "Le Bois de l'Or'. In fact, only the proportion of earlywood is only significant when radius is up to $1,6 \mathrm{~cm}$ (Girardclos et al., 2016).

The last combination is the association of all the dendro-anthracological parameters: heartwood/sapwood, tree-ring width and diameters. Besides the distinction between young and mature woods based on the association between heartwood/sapwood and diameters, it becomes possible to discriminate branches from trunks among young woods. Indeed, branches are characterized by sapwood, a low growth rate and rather downward growth, 
whereas young trunks (coppice and seeded trees) are characterized by sapwood, a high growth rate and rather upward growth.

500

Specific patterns appear depending on the stand and the potential types of wood

502

503

504

505

506

507

508

509

510 exploitation (trunks and/or branches). Thus, anthracological types could be defined forming an interpretative grid which can act as a useful key for the interpretation of archaeological charcoal assemblages. Moreover, the recorded dendrological information is not the same depending on the position in the tree. For example, the information recorded in tree-ring width depends on the position of the charcoal fragment; tree-ring width and growth trend in young woods may be a good indicator of the origin of the wood in the tree (crown or bole) whereas stand characteristics (stand density according to strong or low competition between trees) are more perceptible in trunk, i.e. large diameter of mature wood (Marguerie and Hunot, 2007).

These results entail a new approach to anthracological material. Charcoal fragments have to be sorted according to their position in the stem cross-section and in the tree. For that purpose, an anthracological key based on dendro-anthracological parameters and forming anthraco-groups is proposed (Fig. 12).

Each oak fragment is characterized by a charcoal-pith distance, sapwood/heartwood affiliation and annual tree-ring width. The first division at the threshold of a diameter of $7 \mathrm{~cm}$ is often used by foresters and corresponds to the diameter limit between branches and trunks in deciduous oak forest. Concerning tree-ring width, charcoal fragments with regular and irregular tree-ring width series are taken into account separately. For example in northern France, according to V. Bernard (1998, p. 96), narrow rings are less than 0.7 $\mathrm{mm} /$ year and large rings are between 0.7 and $3 \mathrm{~mm} /$ year for deciduous oak. Very large rings, up to $3 \mathrm{~mm}$, can be also considered (i.e. 12 groups).

The use of this anthracological key enables us to sort charcoal fragments according to their position in the tree. Then, measurements of each batch can be processed separately. 
To close, it is important to make several remarks concerning the dendro528 anthracological tools and their applications.

i) The application of dendro-anthracological tools requires a minimum transversal plane size of about $4 \mathrm{~mm} \times 4 \mathrm{~mm}$ and at least one whole growthring. The optimal number of fragments to analyze is around 100 per sampling unit (structure, layer, etc. according to the problematic).

ii) The choice of the diameter classes, chosen to be compatible with standards used in dendrometrical plans by foresters, seems to be relevant. However, a charcoal fragment can be classified in a class or the other when the value of the charcoal-pith distance is close to a limit but usually the interpretation is not affected.

iii) Given that it exists a boundary between the diameters of trunks and branches within a wood stand and that the part of the trunk located in the crown presents the same dendrological characteristics as a branch, it is more relevant and accurate for charcoal analysis to distinguish bole from crown than trunk from branch when considering oak and probably more generally Angiospermea. However, by Gymnospermea, the trunk can be easily followed until the apex with a clear separation of the branch material. Thus this distinction bole/crown or trunk/branch has to be adapted according to the architecture of the tree. In addition, variations in growth rates are often considered and interpreted in terms of environmental (light, soil or climate) and human factors (clearings or woodland management). However, we have to keep in mind that they can also result from a change in exploitation techniques (whole trees, trunks, branches). The use of the anthracological key may allow for the classification of the growth-ring width signal and thus bring more accurate information. 
iv) Shrinkage during charcoalification leads to lower tree-ring width. This process is not consistent, depending on sapwood/heartwood and charcoal-pith distance. A preliminary study on shrinkage offers promising results in order to propose correction factors (Garcia Martinez and Dufraisse, 2012).

v) The relative frequency of the different taxa in charcoal assemblages is representative of the used biomass (wood volume). In the same way, the use of the dendro-anthracological parameters is based on the assumption that charcoal fragments represent the different parts of trees proportionally to their volume, with their dendrological characteristics (growth, ratio sapwood/heartwood, diameter). That is why the ADmodel is based on wood volume (and not on the number of fragments). However, we stress that, this model cannot reconstruct the quantity of initially burnt wood.

vi) As for the interpretation of tree-ring width (Marguerie, 1992, p. 72; Marguerie and Hunot, 2007), several conditions are required to interpret the dendroanthracological parameters: charcoal assemblages must come from numerous trees, tree-ring series are randomly distributed in the transversal sections of charcoal fragments, ring series must be numerous enough and with a homogeneous width, acquisitions areas are subjected to the same climatic influences and the geological substratum must be homogeneous.

\section{Conclusion}

In line with the work of D. Marguerie (Marguerie, 1992, Marguerie and Hunot, 2007, Marguerie, 2011, Marguerie et al., 2010), combining charcoal identification and dendrological examination, the aim of this study was to improve methods to assess whether it was

578 pertinent to develop quantitative measurements, such as estimating pith-charcoal distance, 579 and whether the combination of dendro-anthracological parameters provides new information on wood exploitation and forest management. 

development of three anthracological tools consisting in i) measuring charcoal-pith distance, ii) discriminating heartwood/sapwood and iii) modelling dendrological data to make them compatible with charcoal analysis. Three dendro-anthracological parameters i.e. growth ring width, charcoal-pith distances and heartwood/sapwood, modelled with ADmodel, were tested on modern-day oak wood stands chosen with respect to historical woodland practices: a coppice-under-standard, an old coppice undergoing conversion to high forest and a young stand formed by a mixture of seeded and coppice trees. For a more realistic representation of dendrological data according to anthracological constraints, different levels of analysis were considered: the whole tree, and trunks and branches separately, allowing us to further consider various modes of wood exploitation.

The dendro-anthracological parameters taken into account independently of each other provide interesting results but rather limited interpretation, especially for tree-ring width or sapwood/heartwood. Indeed the dendrological information cannot be interpreted in the same way depending on its position in the tree. For example, growth conditions and thus paleo-environmental information are essentially recorded in the trunk. In contrast, the combination of the dendro-anthracological parameters highlights specific patterns between organs, stands and regeneration modes, and enables us to establish an anthraco-typology

599 forming an interpretative grid. A major result here is the identification of the position of the 600 charcoal fragment belonging to young woods or internal/middle/external parts of mature woods and the distinction between branches and young trunks when associated with the tree-ring width. These results lead to the establishment of an anthracological key aiming to sort charcoal fragments into anthraco-groups according to their position in the tree and their growth rate.

Finally, these results offer new opportunities for the interpretation of archaeological 606 charcoal assemblages as well as the development of new dendro-anthracological tools 607 adapted to species other than deciduous oak. 


\section{Acknowledgment}

610

611 The authors thank the Agence Nationale de la Recherche (ANR JCJC 200101 DENDRAC, 612 dir. A. Dufraisse) for financing this study and Louise Byrne for English correction. They are 613 also grateful to two anonymous reviewers for their valuable remarks and suggestions which 614 helped to improve this publication.

615

616

\section{Captions}

618 Table 1 Dendrological characteristics of each wood stand and sampled trees.

619 Table 2a Analyzed wood discs and dendrological characteristics: Bogny-sur-Meuse; Les

620 Cagouillères

621 Table 2b Analyzed wood discs and dendrological characteristics: Bois de l'Or.

622

Fig. 1. Dendro-anthracological tools.

624

Fig. 2. General analytical protocol developed in the ANR DENDRAC program. Experimental charcoal assemblages are not considered in this paper.

Fig. 3. Location of sampled stands.

Fig. 4. Main dendrological characteristics of the wood stands: modes of regeneration, average age, average diameter at breast height, relative proportion of trunks and branches (expressed according to volume), distribution of the diameters of trunks and branches (each

$633 \log$ and its volume was attributed to an unburnt wood diameter class), average growth rate

634 and growth trends (tree-ring width measurements were taken on each disc at a height of 1.30 $\mathrm{m}$, along 5 radii and averaged). 
637 Fig. 5. Annual ring-width was averaged from 5 radii in each disc. (a) Distribution of annual 638 ring-width (maximum and minimum values, 1st and 3rd quartiles and median) considering 639 whole trees (white), trunks (brown) and branches (green). (b) Distribution of the annual ring640 width along the trunks and in branches.

641

642 Fig. 6. Relative proportion of heartwood (brown) and sapwood (yellow) for each stand, 643 considering whole trees, trunks and branches. The volume proportion of sapwood and 644 heartwood was estimated for each disc, then each log and tree, and averaged for each wood 645 stand. The average number of sapwood tree-rings, average sapwood width $(\mathrm{cm})$ and 646 average sapwood growth rate ( $\mathrm{mm} /$ year) are indicated in boxes when heartwood is present.

648 Fig. 7. Diameter distribution (each log with its volume was attributed to a diameter class). At 649 the top, the raw dendrological data (UWD = Unburnt Wood diameter) with trunks in brown 650 and branches in green (branch $=100 \%$ and trunk $=100 \%$ ). At the bottom, the decomposed 651 UWD for the whole trees, trunks and branches for each stand.

652

653 Fig. 8. Dendrological data (simple line): average tree-ring width calculated by cambial age. 654 Modelled anthracological data (solid line): average tree-ring width calculated for each 655 diameter class.

656

Fig. 9 Cumulated curves of sapwood and heartwood proportions according to the 658 decomposed UWD.

Fig. 10. Average tree-ring width according to the diameter classes (decomposed UWD) and their respective affiliation to sapwood (yellow) or heartwood (brown).

Fig. 11. Anthraco-typology for deciduous oak: an interpretative grid for archaeological 664 charcoal assemblages. 
Fig. 12. Anthracological key for deciduous oak to sort archaeological charcoal fragments into

667

668

669

670

671

672

673

674

675

676

677

678

679

680

681

682

683

684 Deleuze, C., Monreau, F., Renaud, J.P., Vivien, Y., Rivoire, M., Santenoise, Ph., 685 Longuetaud, F., Mothe, F., Hervé, J.C., Vallet, P., 2014. Estimer le volume total d'un arbre, 686 quelles que soient l'essence, la taille, la sylviculture, la station. RDV Techniques 44, ONF, 687 pp. 22-32. anthraco-groups. First, charcoal fragments are separated according to the charcoal-pith distances, more or less than $3.5 \mathrm{~cm}$ (i.e. diameter of $7 \mathrm{~cm}$ ). Next, the charcoal fragment is attributed to heartwood or sapwood according to the proportion of vessels sealed by tylosis. Lastly, each fragment is characterized by annual tree-ring width.

\section{References}

Bernard, V., 1998. L'Homme, le bois et la forêt dans la France du Nord entre le Mésolithique et le Haut Moyen-Âge. BAR International Series, 733, Oxford.

Billamboz, A., 2011. Applying dendro-typology to large timber series. In Fraiture P. (Ed), Tree Rings, Art, Archaeology Proceedings of an international Conference. Brussels, pp. 177-188.

Billamboz, A., 2014. Regional patterns of settlement and woodland developments: Dendroarchaeology in the Neolithic pile dwellings on Lake Constance (Germany). The Holocene 24 (10), 1278-1287. 
689 Dhôte, J.F., Hatsch, E., Rittié, D., 1997. Profil de la tige et géométrie de l'aubier chez le 690 Chêne sessile (Quercus petraea Liebl.). Bulletin Technique de l'ONF 33, 59-82.

691

692 Dufraisse, A., Coubray, S., Girardclos, O., Dupin, A., Lemoine, M., 2016. Contribution of 693 tyloses quantification in early wood oak vessels to archaeological charcoal analyses: 694 estimation of a minimum age and influences of physiological and environmental factors. 695 Quaternary International (under review).

696

697 Dufraisse, A., Garcia Martinez, M.S., 2011. Mesurer les diamètres du bois de feu en 698 anthracologie. Outils dendrométriques et interprétation des données. Anthropobotanica (2), $699 \quad 1-18$.

700

701 Dufraisse, A., 2012. Firewood and woodland management in their social, economic and 702 ecological dimensions. New perspectives. In Badal E., Carrion Y., Grau E., Macías M., 703 Ntinou M. (Eds), Wood and charcoal: evidence for human and natural history. Saguntum 704 extra $13,65-74$.

705

706 Dufraisse, A., 2006. Charcoal anatomy potential, wood diameter and radial growth. In: 707 Dufraisse, A. (Ed.), Charcoal analysis: New Analytical Tools and Methods for Archaeology, 708 BAR International Series, 1483, pp. 47-59.

710 Dufraisse, A., 2002 Les Habitats littoraux néolithiques des lacs de Chalain et Clairvaux (Jura, 711 France): collecte du bois de feu, gestion de l'espace forestier et impact sur le couvert 712 arboréen entre 3700 et 2500 av. J.-C. Analyses anthracologiques, thèse de doctorat, univ. 713 De franche-Comté, 349 p. 
715 Fritts, H. C., 1976. Tree Rings and Climate. Academic Press, New York, New York.

716

717 Garcia Martinez, M.S., Dufraisse, A., 2012. Correction factors on archaeological wood

718 diameter estimation. In Badal E., Carrion Y., Grau E., Macías M., Ntinou M. (Eds), Wood and 719 charcoal: evidence for human and natural history. Saguntum extra 13, 283-290.

721 Gaudin, S., 1996. Dendrométrie des peuplements. BTSA Gestion Forestière, Besançon.

723 Girardclos, O, Dufraisse, A., Dupouey, J.L., Coubray, S., Hamdidi, B., Ruelle, J., Rathgeber, 724 C., 2016. Improving identification of coppiced and seeded tress in past woodland 725 management by comparing growth and wood anatomy of living sessile oaks (Quercus petraea). Quaternary International (under review).

Haneca, K., Van Acker, J., Beeckman, H., 2005. Growth trends reveal the forest structure during Roman and Medieval times in Western Europe: a comparison between archaeological and actual oak ring series (Quercus robur and Quercus petraea). Annals of Forest Science $62(8), 797-805$.

Lebourgeois, F., 1999. Les chênes sessile et pédonculé (Quercus petraea Liebl. et Quercus robur L.) dans le réseau RENECOFOR : rythme de croissance radiale, anatomie du bois, de l'aubier et de l'écorce. Revue Forestière Française 51 (4), 522-536.

737 Marguerie, D., 2011. Short Tree ring series: the study materials of the dendro-anthracologist. 738 In Badal E., Carrion Y., Grau E., Macías M., Ntinou M. (Eds), Ve International Meeting of 
739 charcoal analysis. The charcoal as cultural and biological heritage. Saguntum extra 11, 1574016.

741

742 Marguerie, D., Bernard, V., Begin, Y., Terral, J.-F., 2010. Dendroanthracologie. In Payette S.,

743 Filion L. (Dir.), Dendroécologie: principes, méthodes et applications/Dendroecology:

744 principles, methods and applications. Presses Universitaires Laval, Québec, Canada, 311745347.

746

747 Marguerie, D. Hunot, J.-Y., 2007. Charcoal analysis and dendrology: data from 748 archaeological sites in western France. Journal of Archaeological Sciences, 34 (9), $1417-$ 7491433.

750

751 Marguerie, D., 1992. Evolution de la végétation sous l'impact humain en Armorique du 752 Néolithique aux périodes historiques. Trav. Labo. Anthropologie, Université de Rennes I, $753 \quad n^{\circ} 40,313 p$.

754

755 Michon, G., 2005. Domesticating forests. How farmers manage forest resources. IRD756 CIFOR-ICRAF, Paris-Jakarta-Bogor.

758 Michon, G., 2015. Agriculteurs à l'ombre des forêts du monde. Agroforesteries vernaculaires. 759 Actes Sud/IRD, Arles.

761 Paradis-Grenouillet, S., Dufraisse, A., Allee, P., 2013. Radius of curvature measurements 762 and wood diameter: a comparison of different image analysis techniques. In F. Damblon 
763 (Ed.), 4th International Meeting of Anthracology in Brussels. BAR International Series 2486, $764 \quad 173-182$.

765

766 Picornell Gelabert, LI., 2011. People, trees and charcoal: somes reflections about the use of 767 ethnoarchaeology in archaeological charcoal analysis. In Badal E., Carrion Y., Grau E., 768 Macías M., Ntinou M. (Eds), Ve International Meeting of charcoal analysis. The charcoal as 769 cultural and biological heritage. Saguntum extra 11, 185-186.

770

771 Rondeux, J, 1999. La mesure des arbres et des peuplements forestiers. Les presses 772 agronomiques de Gembloux, Gembloux.

773

774 Salavert, A., Dufraisse, A. 2014. Understanding the impact of socio-economic activities on 775 archaeological charcoal assemblages in temperate areas: comparative analysis of firewood 776 management of two Neolithic societies of Western Europe (Belgium, France). Journal of 777 Anthropological Archaeology 35, 153-163.

778

779 Théry-Parisot I., Dufraisse A., Chzrazvzez J., Henry A., Paradis-Grenouillet S. 2011. 780 Charcoal analysis and wood diameter: inductive and deductive methodological approaches 781 for the study of firewood collecting practices. In Badal E., Carrion Y., Grau E., Macías M., 782 Ntinou M. (Eds), Ve International Meeting of charcoal analysis. The charcoal as cultural and 783 biological heritage. Saguntum extra 11, 31-32. 


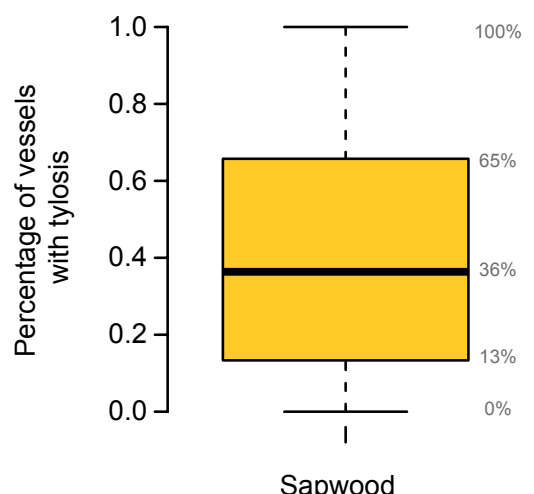

Sapwood
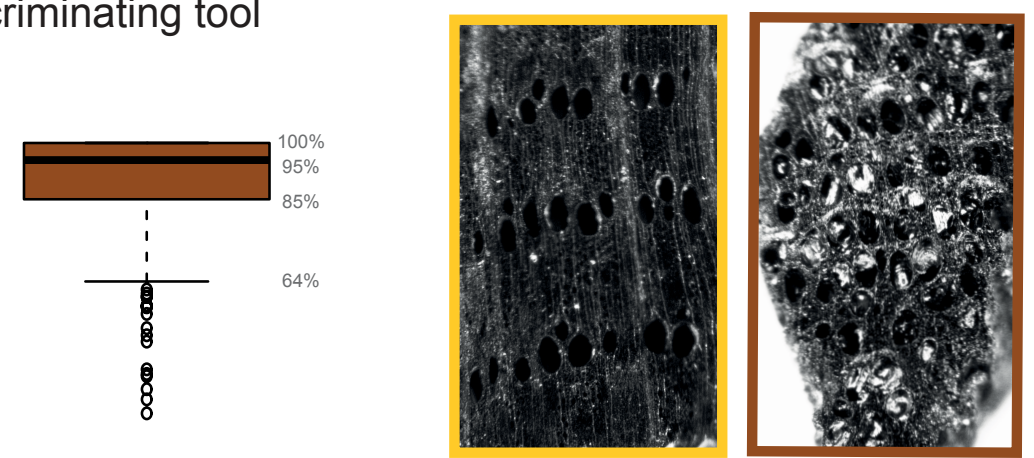

$1 \mathrm{~mm}$

Heartwood

b- Pith estimation tool

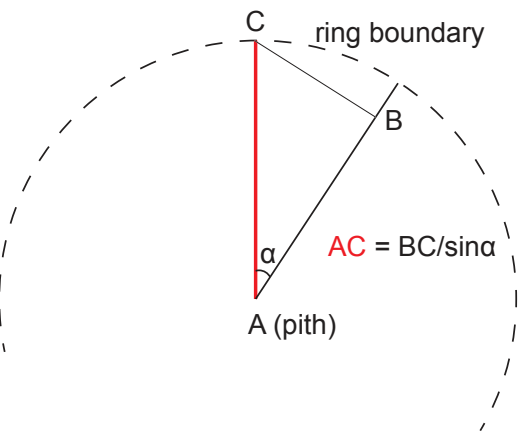

$\alpha$ : angle between 2 ligneous rays $\mathrm{BC}$ : distance between 2 ligneous rays $\mathrm{AC}$ : pith-charcoal distance

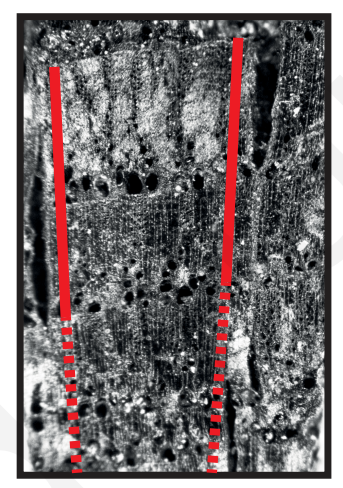

$1 \mathrm{~mm}$

c- Analysis Diameter tool
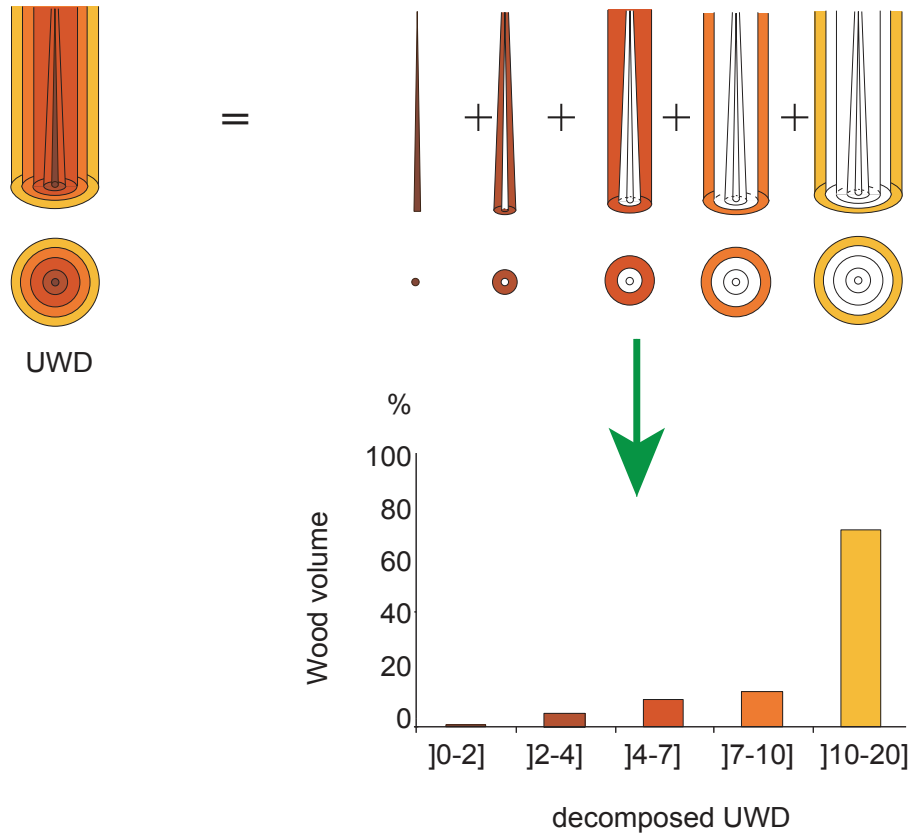


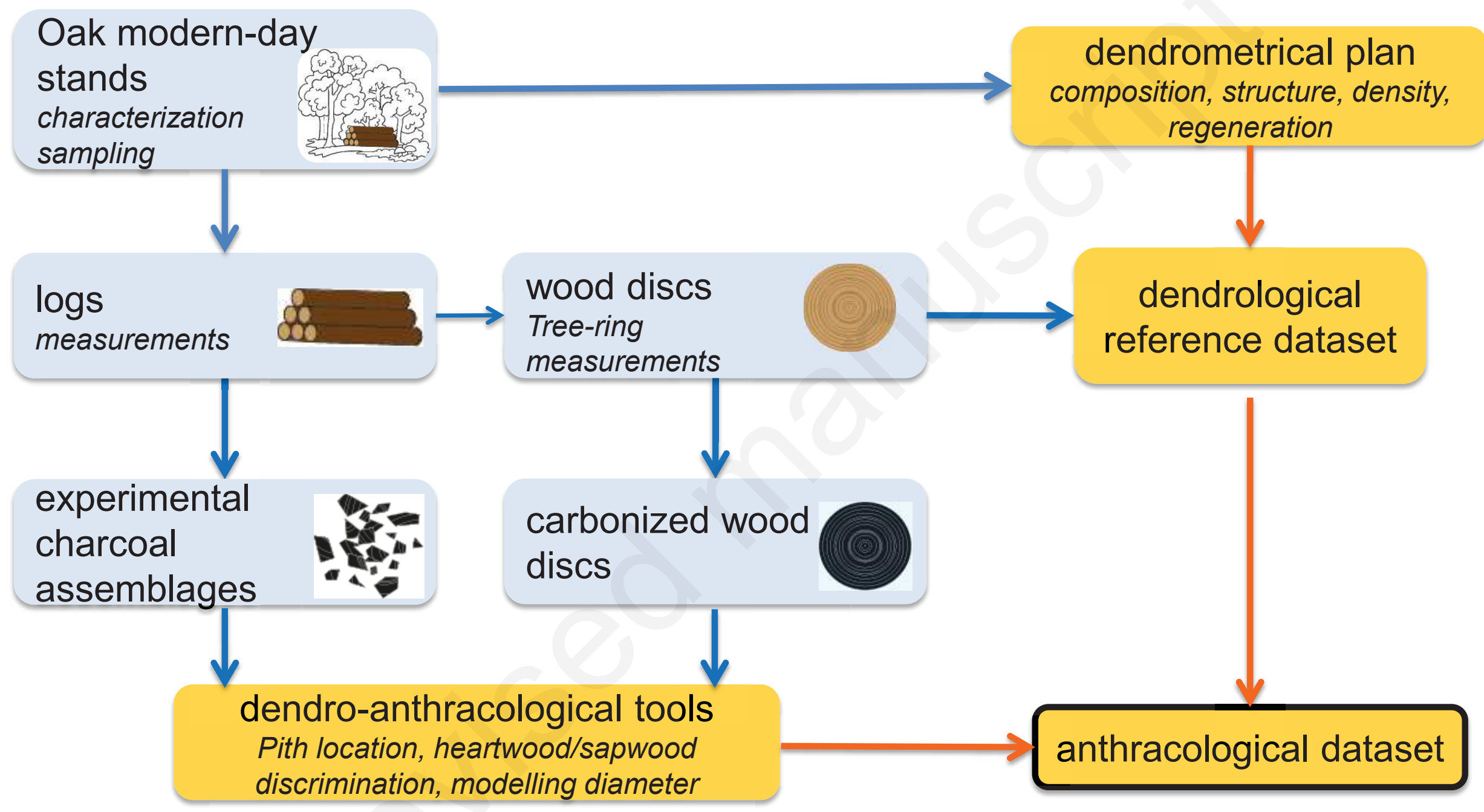




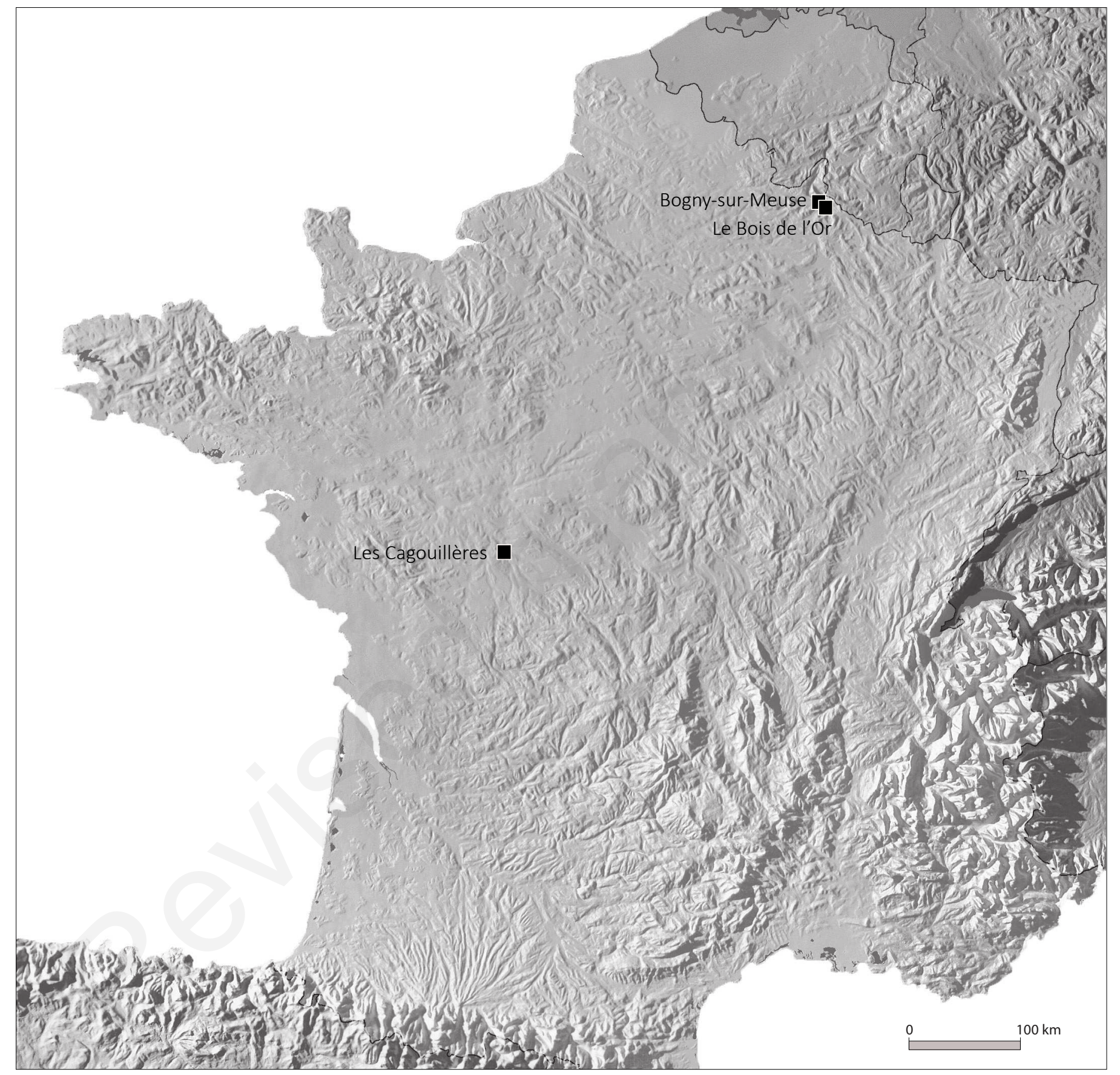




\section{Les Cagouillères}

Abandonned old coppice

4 trees

Average age $=62 \mathrm{yr}$

Average diameter $=20.75 \mathrm{~cm}$

Average tree-ring width $=1.23 \mathrm{~mm}$

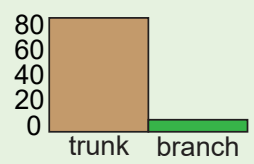

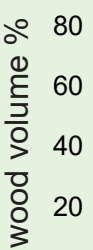

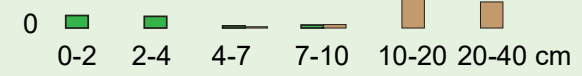
Unburnt Wood Diameter

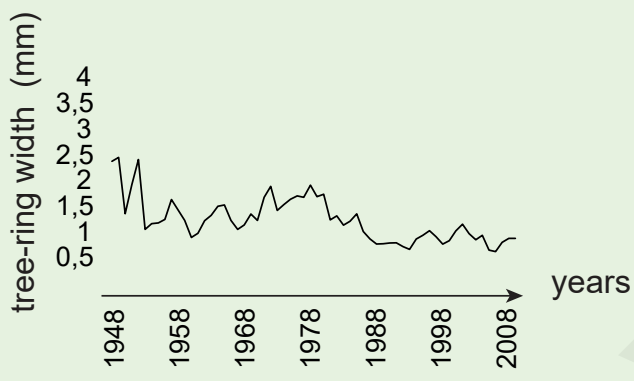

\section{Bogny-sur-Meuse}

Dominant standard

1 tree

Age $=68 \mathrm{yr}$

Diameter $=33 \mathrm{~cm}$

Average tree-ring width $=1.35 \mathrm{~mm}$
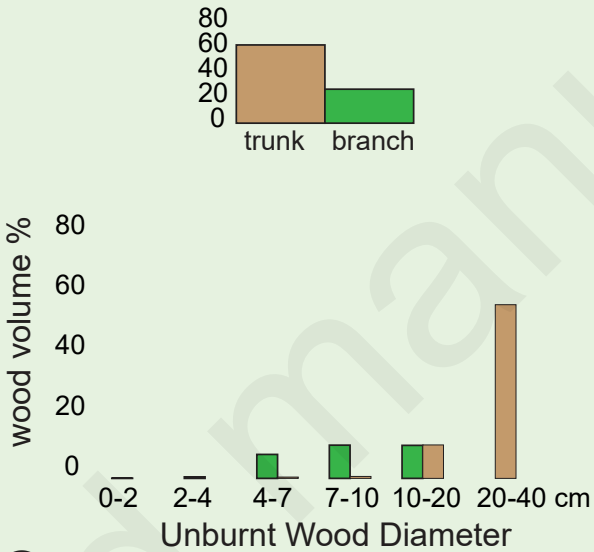

हิ

है 4

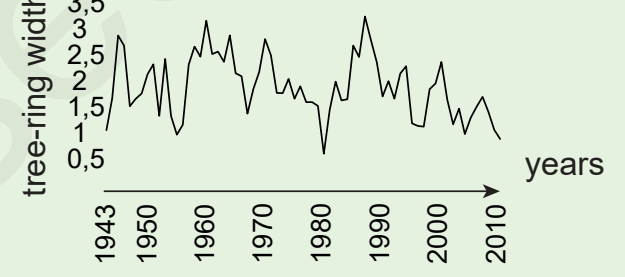

Bois de l'Or

Mixture of seeded and coppiced trees

Average age $=14 \mathrm{yr}$

Average diameter $=10.21 \mathrm{~cm}$

Average tree-ring width $=2.99 \mathrm{~mm}$
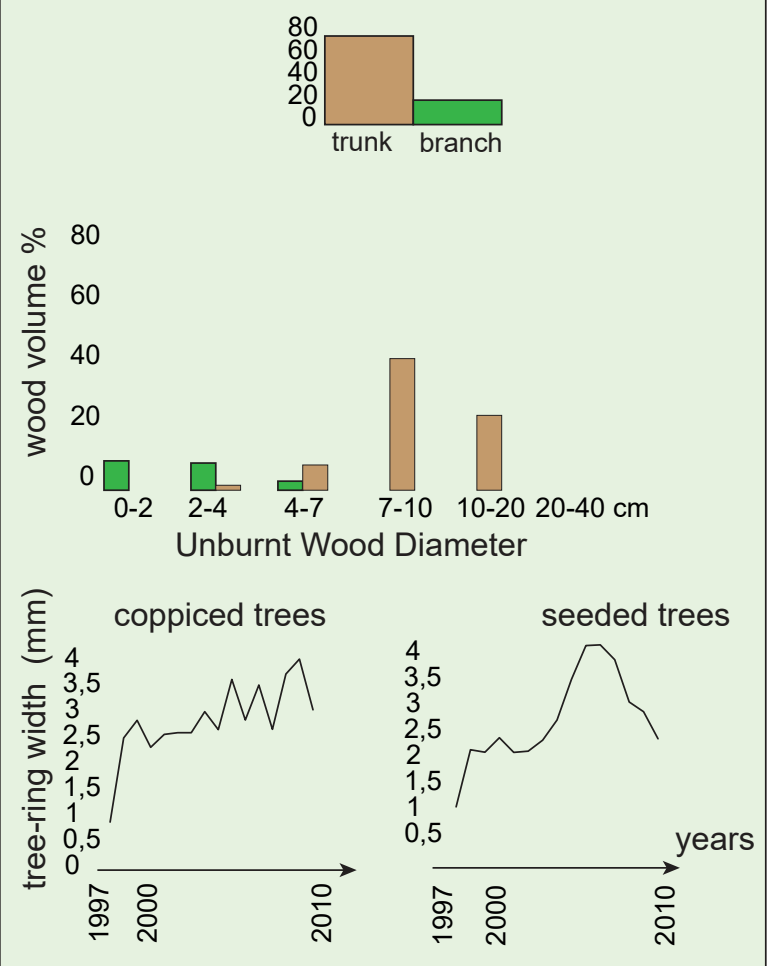
Average tree-ring width $(1 / 100 \mathrm{~mm})$

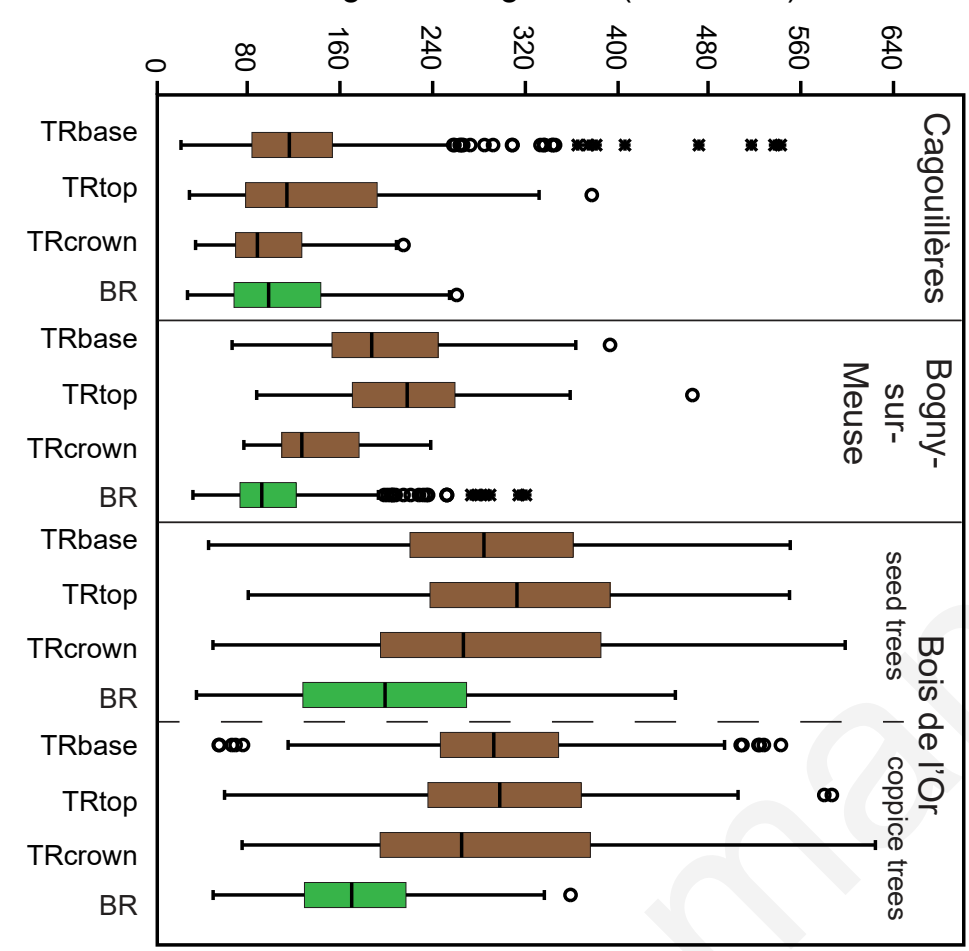

Average tree-ring width $(1 / 100 \mathrm{~mm})$

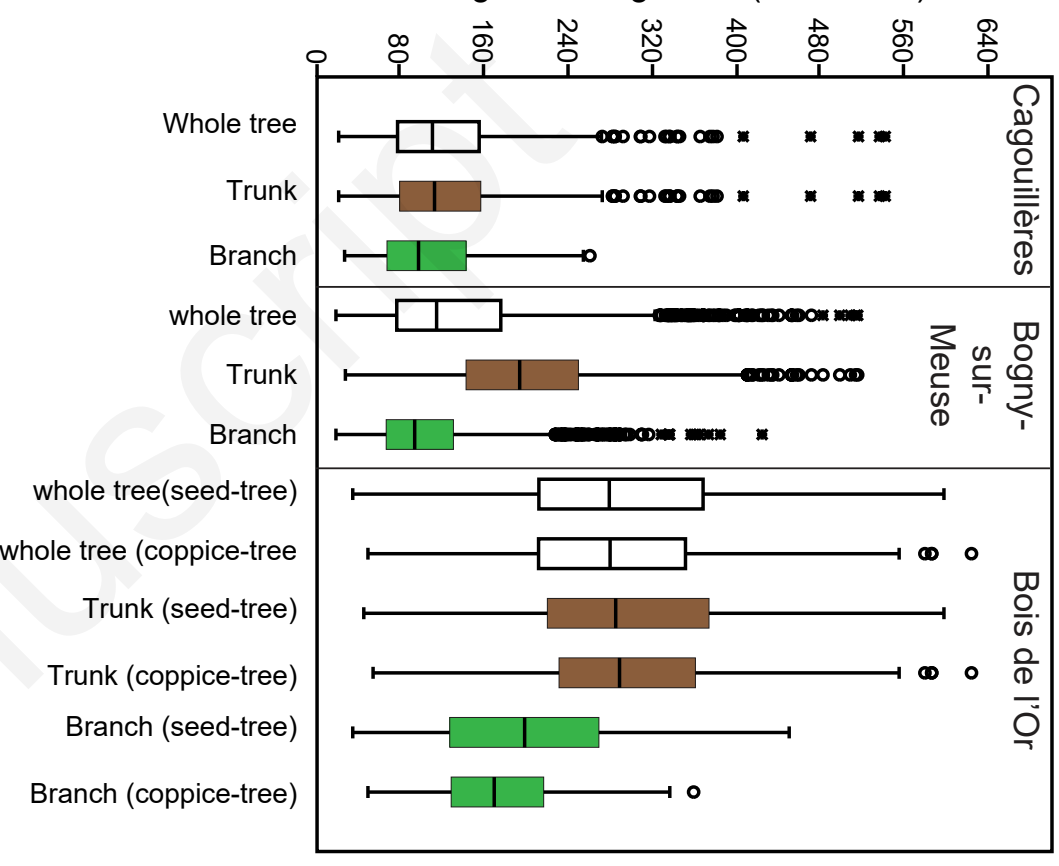






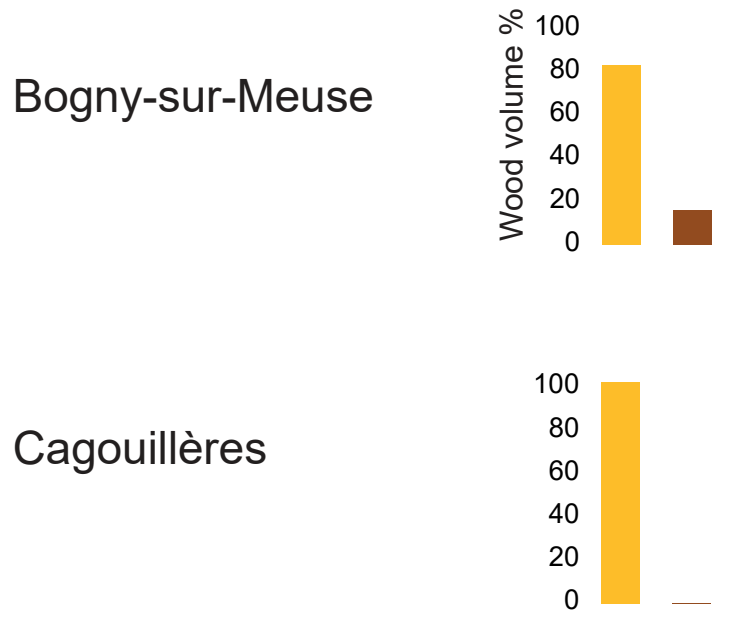
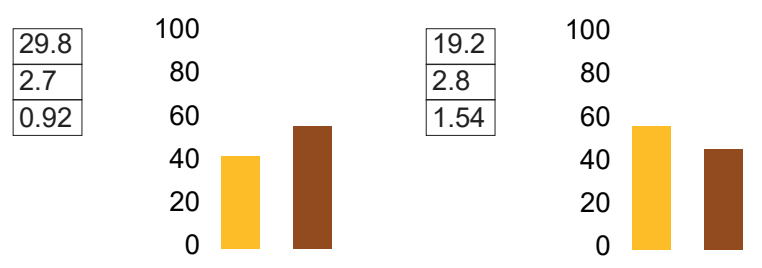

Bois de l'or
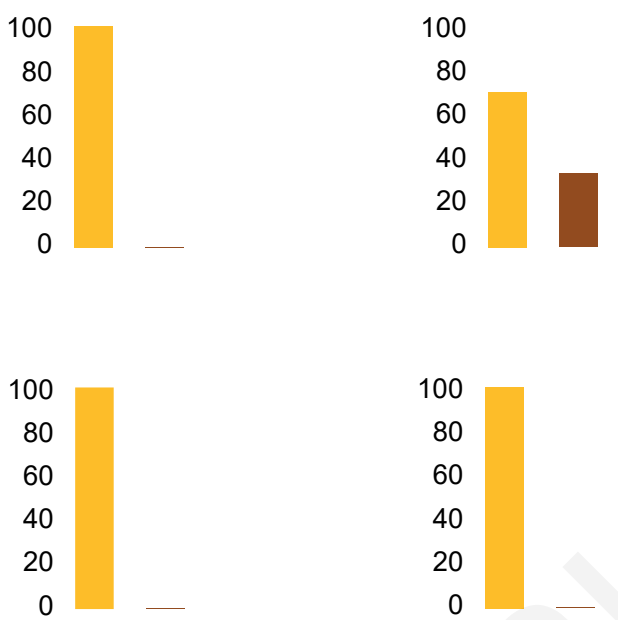

\begin{tabular}{|l|}
\hline 26 \\
\hline 2.5 \\
\hline 0.96 \\
\hline
\end{tabular}

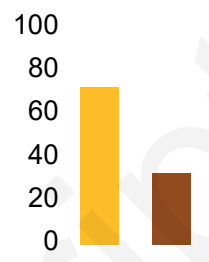

100
80
60
40
20
0

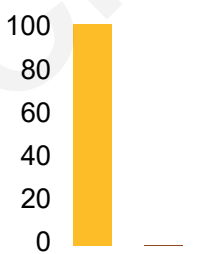

Number of sapwood tree-rings

Sapwood width $(\mathrm{cm})$

sapwood

Average tree-ring width (mm/year)

heartwood 
Cagouillères

trunk (100\%) $\square$ branch (100\%)
Bogny-sur-Meuse
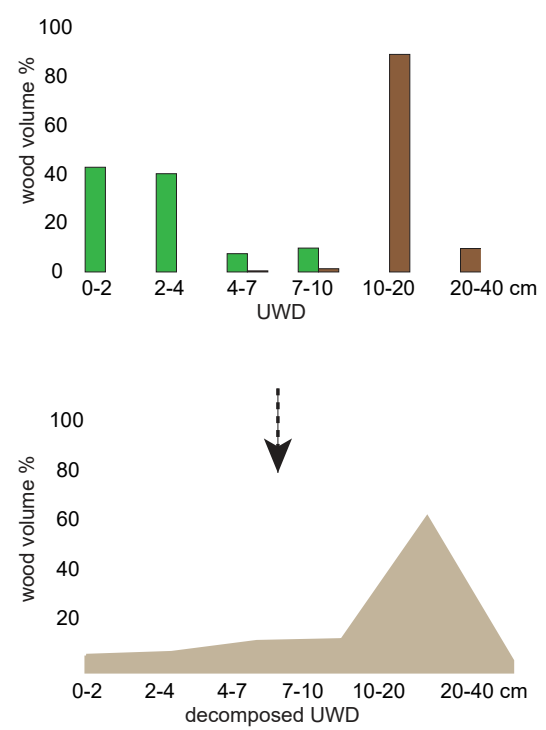

100

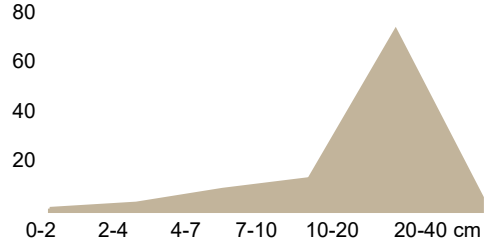

\section{0}

80

60

40

branches

100

80

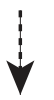

60

40

20

100

80

60

40

20

100

80

60

40

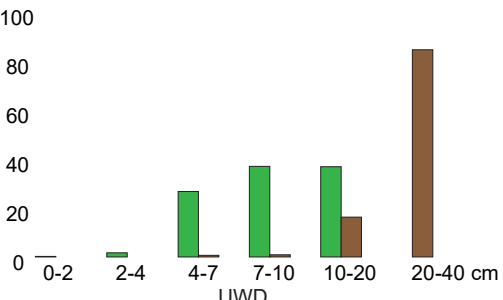

100

80

60
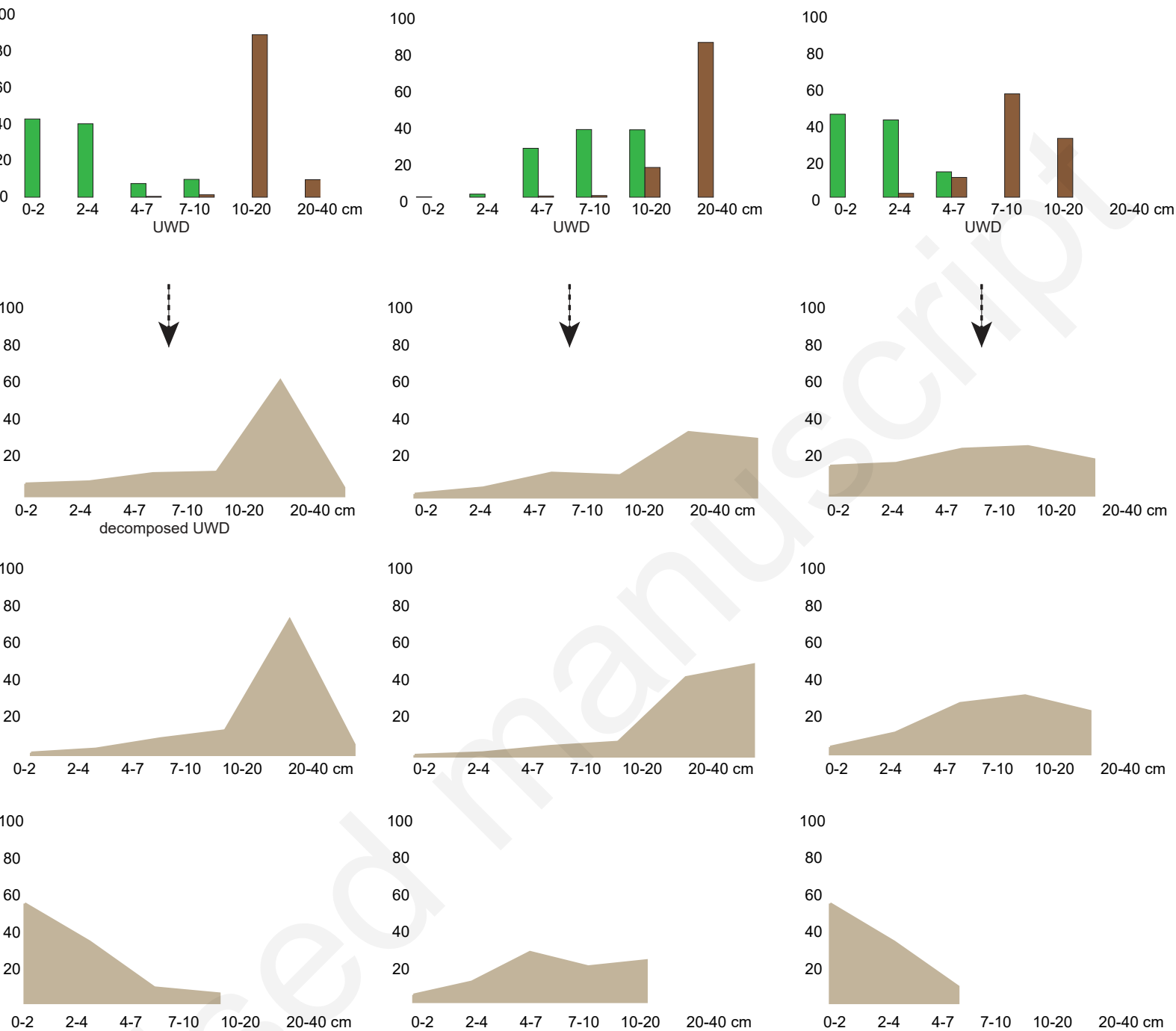

Bois de l'Or

(seeded and coppiced trees)

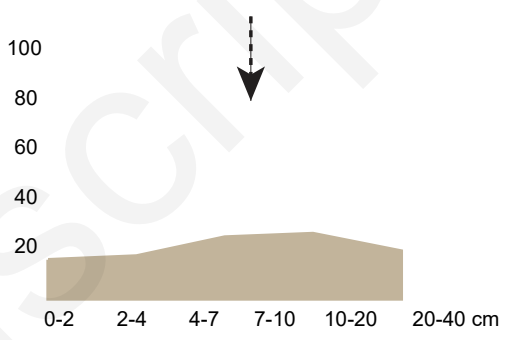

100

80

60

40

20

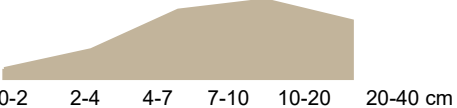

100

80

40

$0-2 \quad 2-4 \quad 4-7 \quad 7-10 \quad 10-20 \quad 20-40 \mathrm{~cm}$ 
Bogny-sur-Meuse
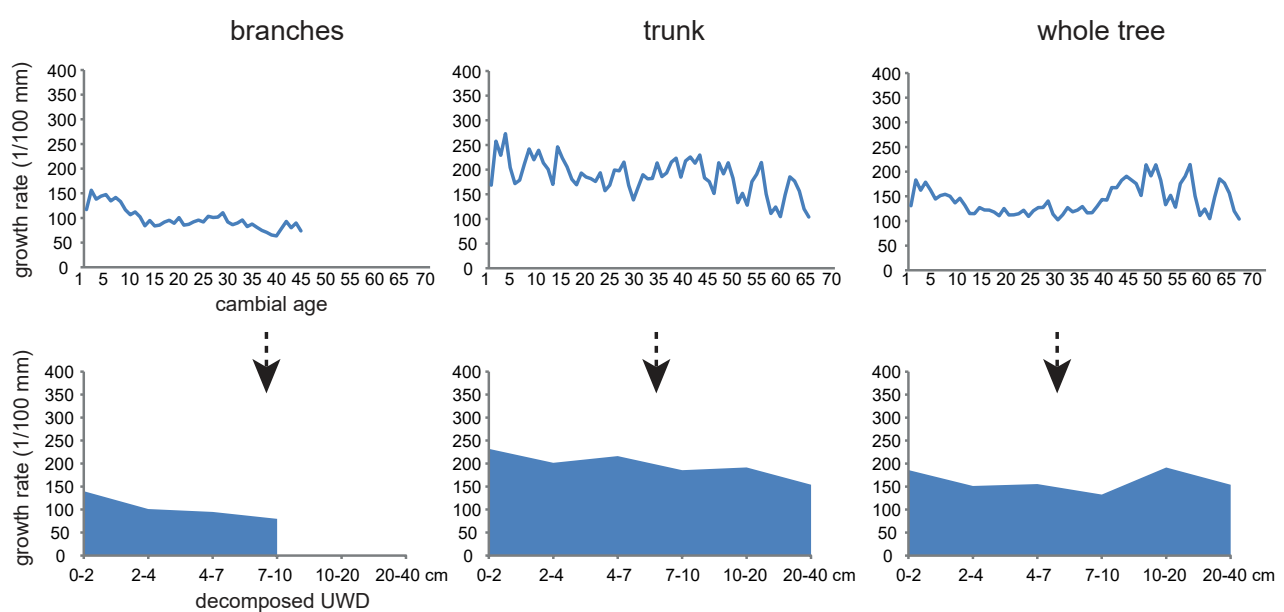

Cagouillères
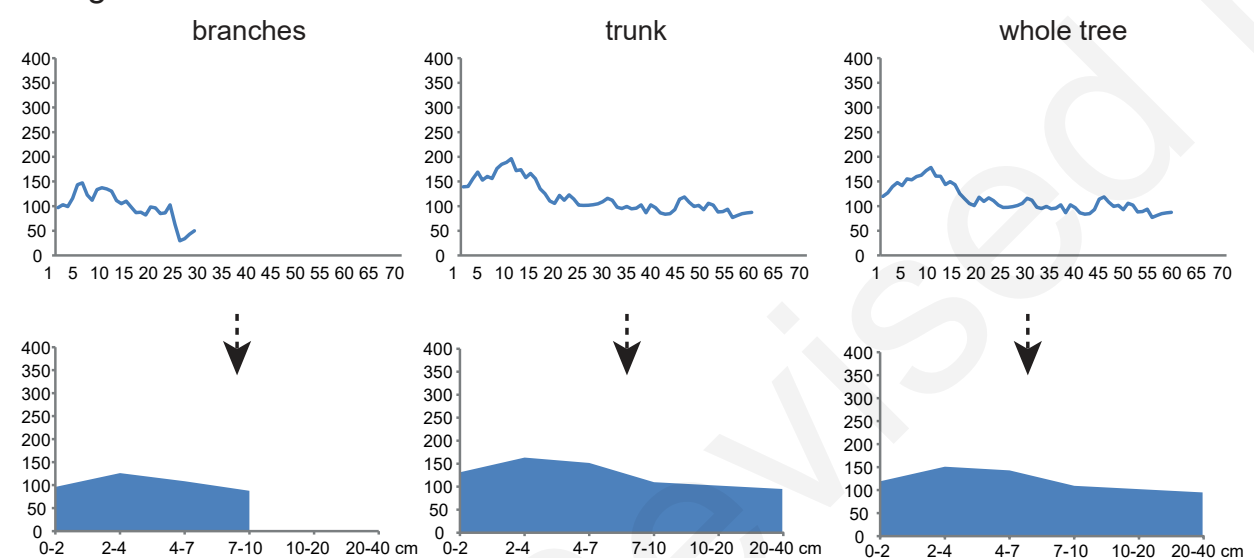

Bois de l'or - coppiced trees


Bois de l'or - seeded trees
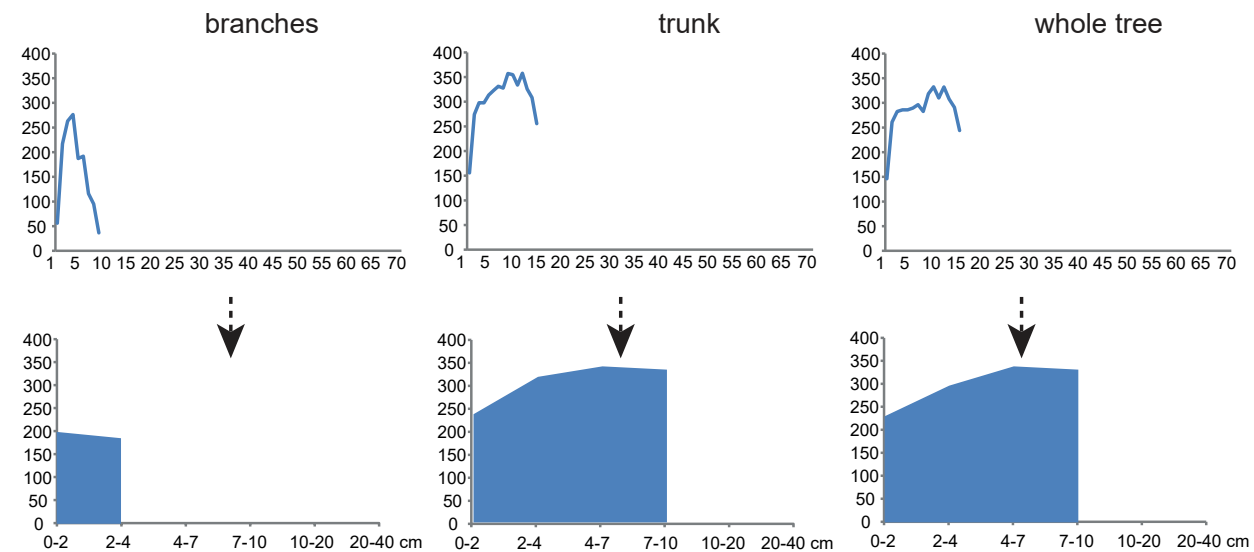
Cagouillères

100

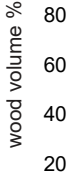

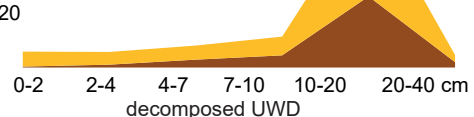
decomposed UWD

100

80

trunk 60

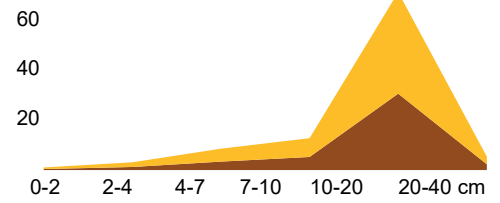

100

80

60

branches

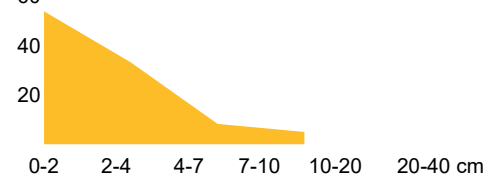

Bois de l'Or

(seeded and coppiced trees)

$100-100$

$80 \quad 80$

$60 \quad 60$

$40 \quad 40$

20

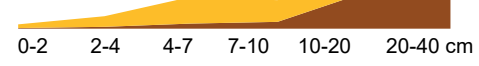

100

80

60

40

20

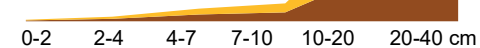

100

80

60

40

20

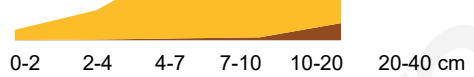

20

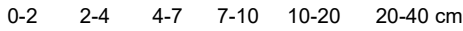

100

80

60

40

20

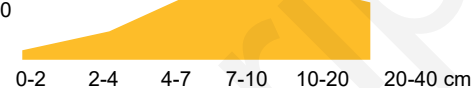

100

80

60

40

20

0-2 $\quad 2-4 \quad 4-7 \quad 7-10 \quad 10-20 \quad 20-40 \mathrm{~cm}$ 

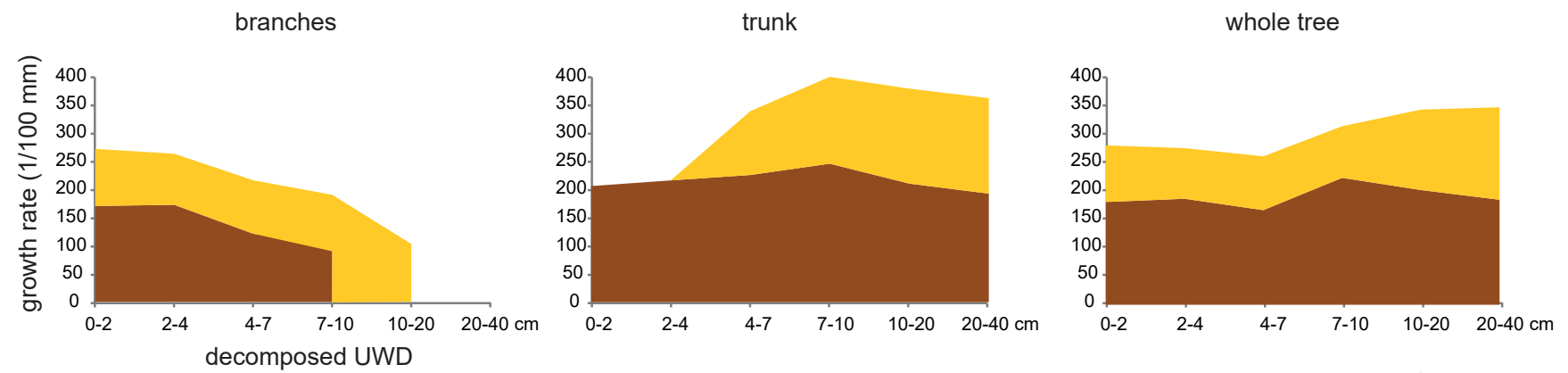

\section{Cagouillères}
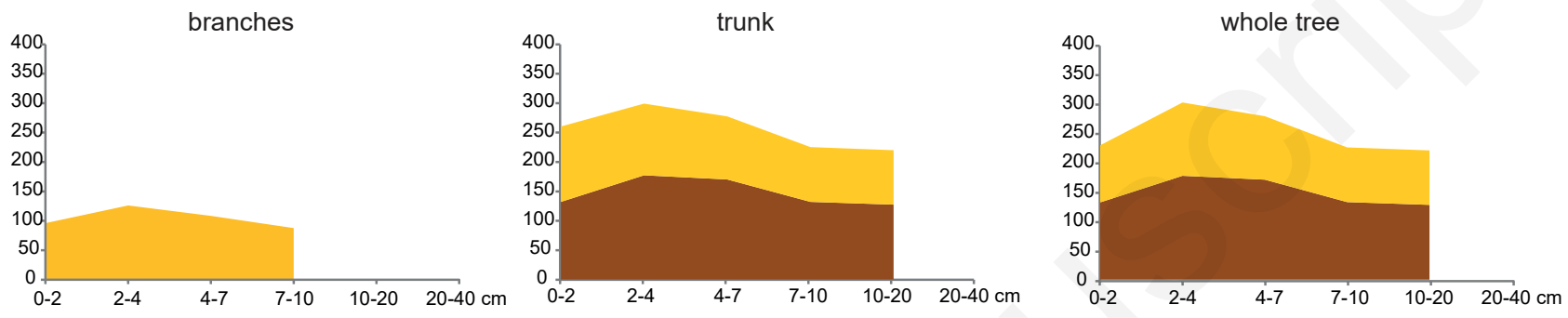

Bois de l'Or- seeded trees

branches

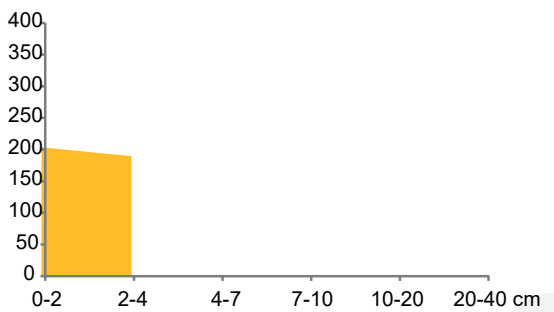

trunk

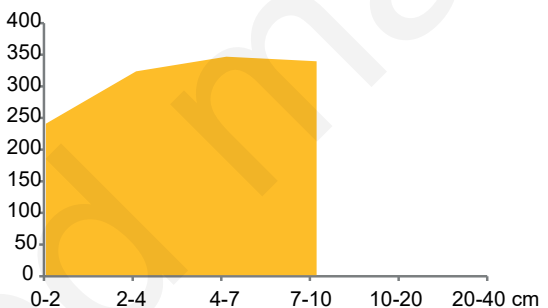

whole tree

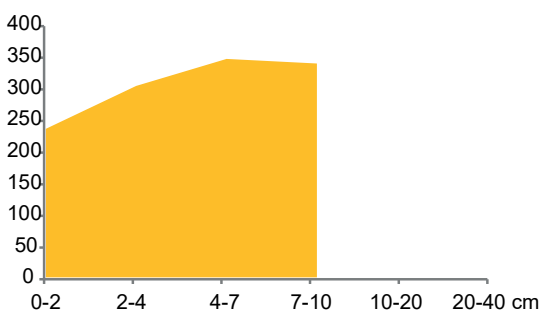

\section{Bois de l'Or- coppiced trees}

branches

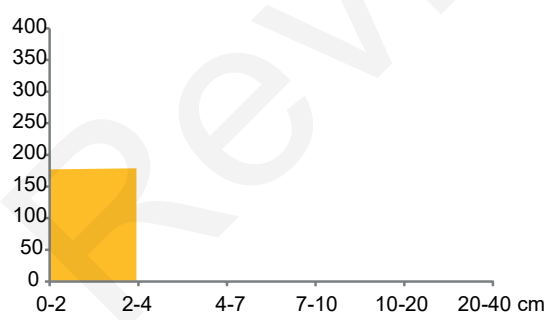

trunk

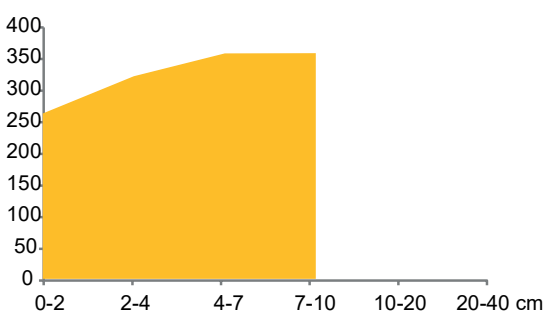

whole tree

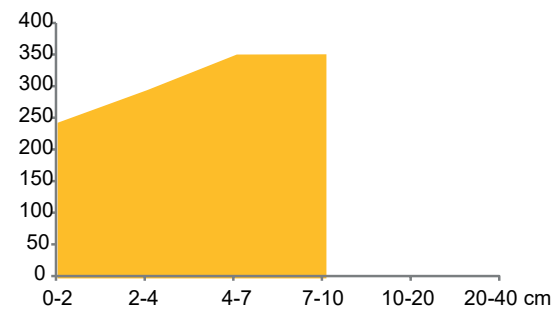



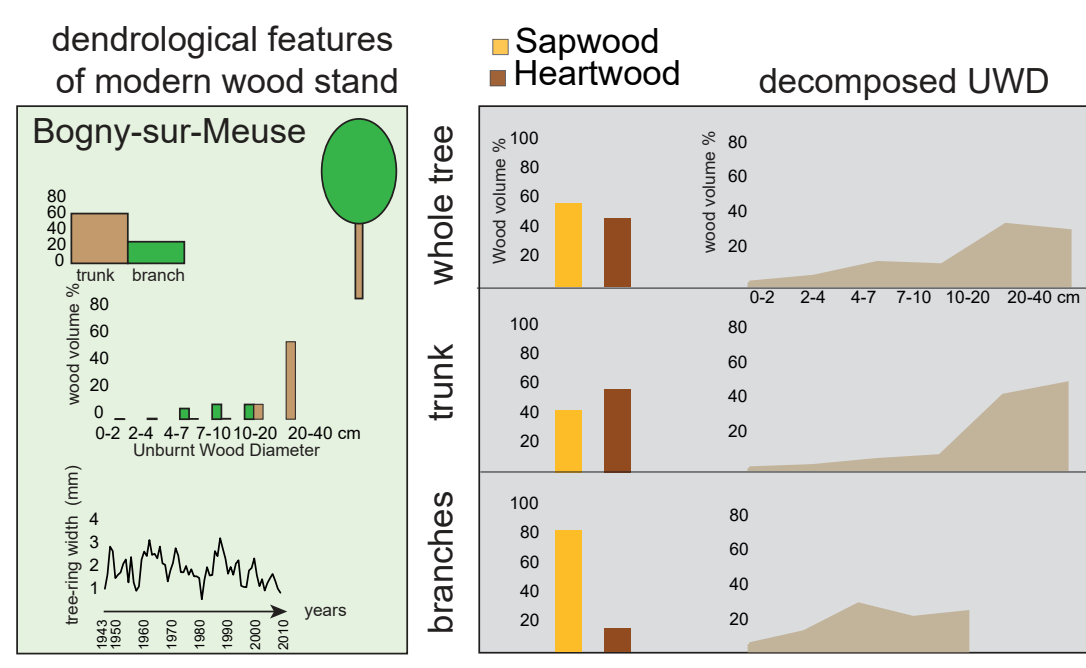

annual tree-ring width

vs decomposed UWD
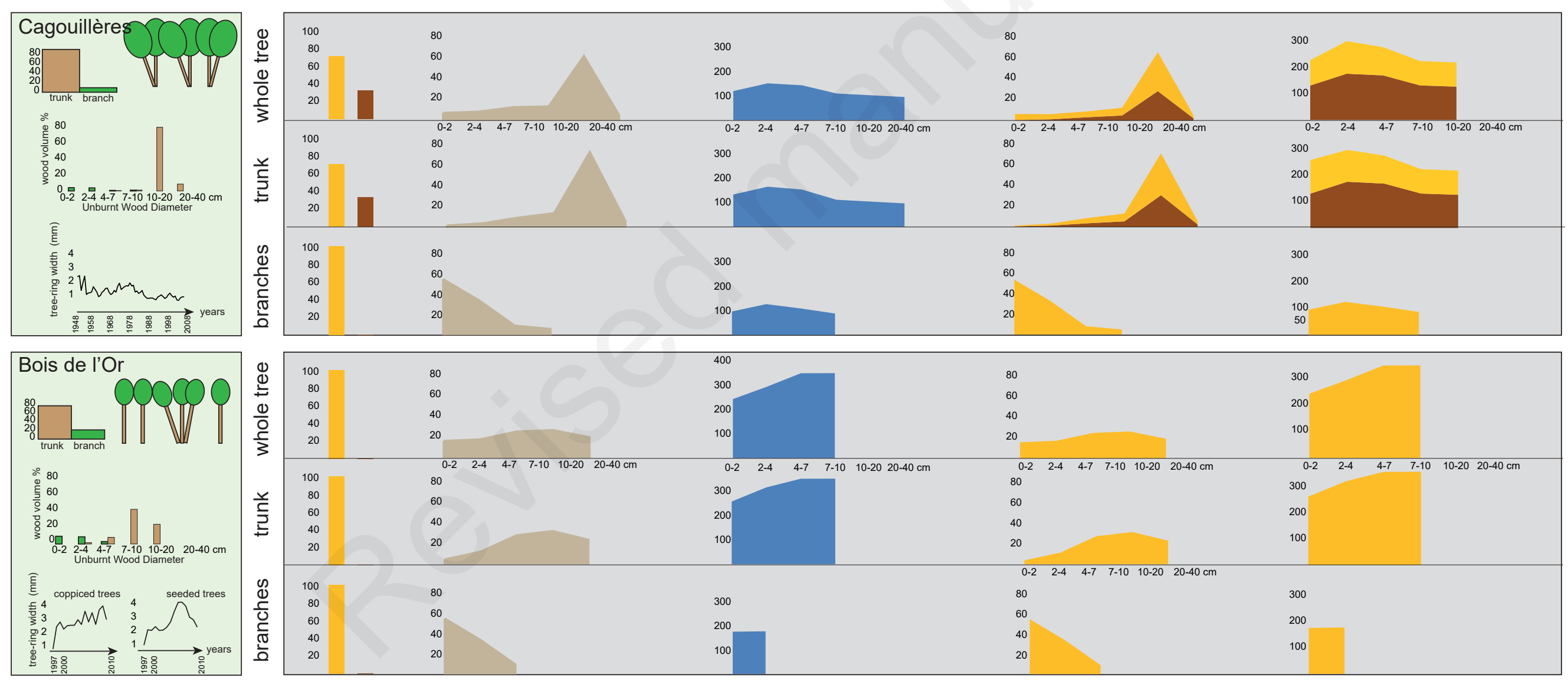
REGULAR WIDTH RINGS

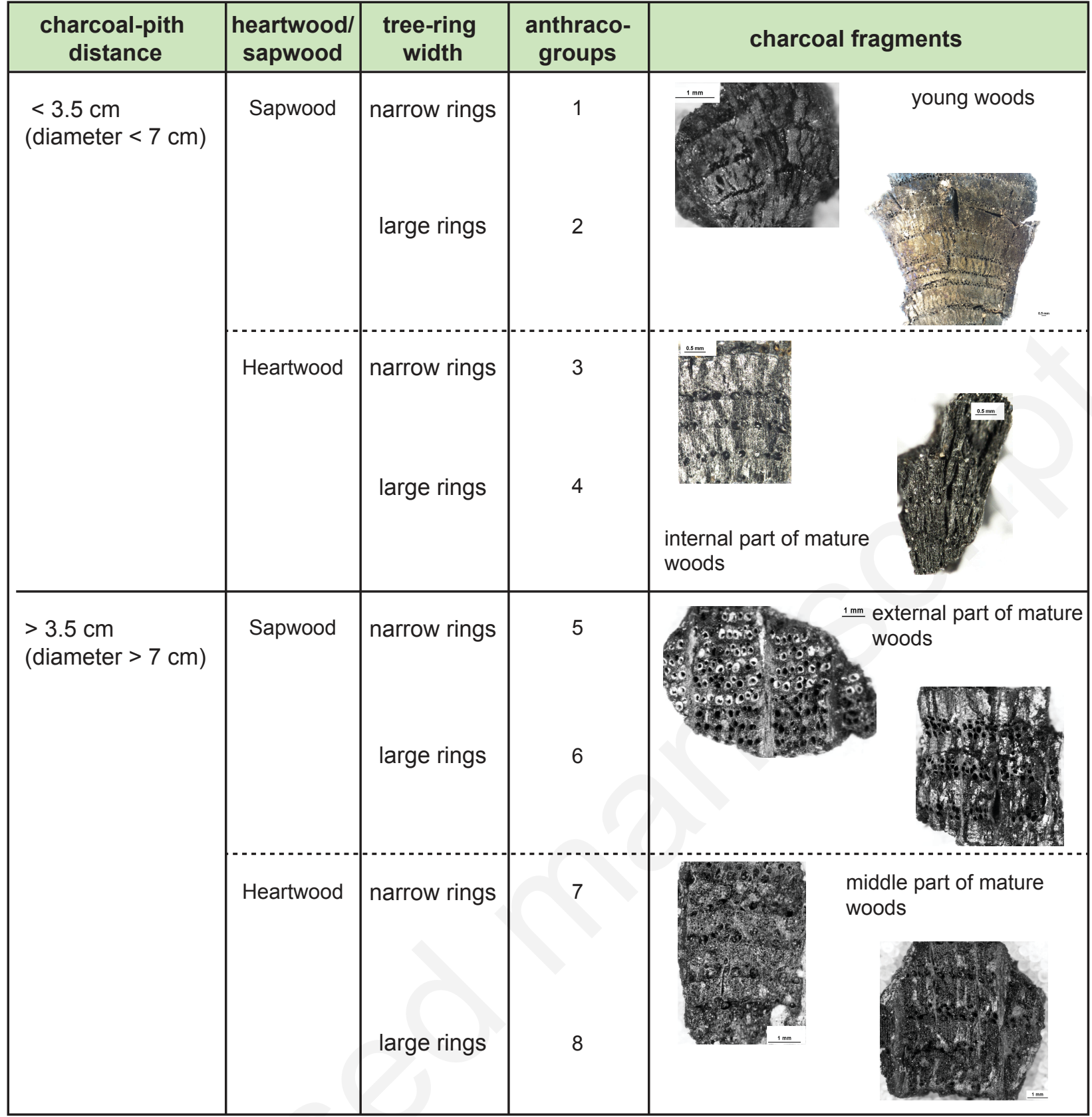

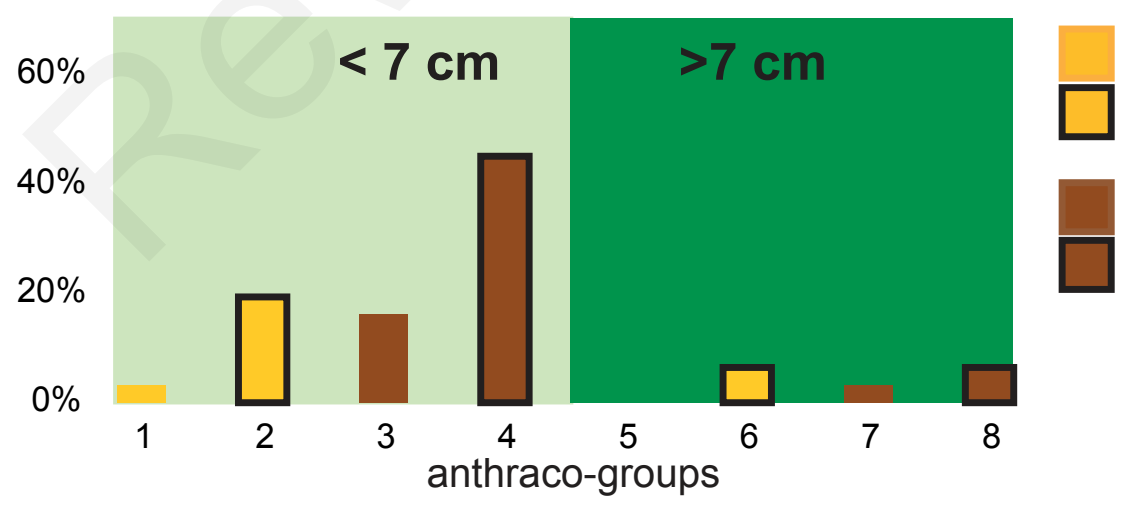

sapwood with narrow rings sapwood with large rings

heartwood with narrow rings heartwood with large rings 


\section{SITES}

\begin{tabular}{|c|c|c|c|c|c|}
\hline \multirow{2}{*}{\multicolumn{2}{|c|}{ Dendrological characteristics }} & \multirow{2}{*}{\multicolumn{2}{|c|}{ Le Bois de l'or }} & \multirow{2}{*}{ Bogny-sur-Meuse } & \multirow[b]{2}{*}{ Les Cagouillères } \\
\hline & & & & & \\
\hline & Description & Self seeded an & coppice trees & $\begin{array}{l}\text { Dominant tree of a coppice- } \\
\text { under-standard }\end{array}$ & Abandoned old coppice \\
\hline & Age & $<15$ ye & ars old & 68 years old & About 60 years old \\
\hline & Substratum & Brown soil & n schists & Brown soil on schists & Calcareous plateau \\
\hline \multirow{3}{*}{$\begin{array}{l}\text { Trees with a diameter } \\
\text { less than } 7.5 \mathrm{~cm}\end{array}$} & basal area increment $\left(\mathrm{m}^{2} / \mathrm{ha}\right)$ & 6 . & & 2.7 & - \\
\hline & $\begin{array}{l}\text { stand density (number of stems } \\
\text { /ha) }\end{array}$ & 49 & & 2387 & - \\
\hline & average square diameter $(\mathrm{cm})$ & 4. & & 3.8 & - \\
\hline \multirow{4}{*}{$\begin{array}{l}\text { Trees with a diameter } \\
\text { more than } 7.5 \mathrm{~cm}\end{array}$} & basal area increment $\left(\mathrm{m}^{2} / \mathrm{ha}\right)$ & 7. & & 20 & - \\
\hline & $\begin{array}{l}\text { stand density (number of stems } \\
\text { /ha) }\end{array}$ & 10 & & 462 & 1300 \\
\hline & average square diameter $(\mathrm{cm})$ & 9 . & & 23.5 & - \\
\hline & dominant height $(\mathrm{m})$ & 9 . & & 22.2 & 18 \\
\hline \multirow[t]{8}{*}{ Sampled trees } & description & coppice trees & $\begin{array}{l}\text { self-seeded } \\
\text { trees }\end{array}$ & Dominant tree & coppice trees \\
\hline & number of sampled trees & 5 & 5 & 1 & 4 \\
\hline & $\begin{array}{l}\text { average square diameter at } 1,3 \\
\mathrm{~m}(\mathrm{~cm})\end{array}$ & 10.4 & 10 & 30.6 & 20.75 \\
\hline & total height $(\mathrm{m})$ & 8.8 & 8.5 & 20.3 & 17.7 \\
\hline & ratio height/diameter $(\mathrm{m} / \mathrm{m})$ & 84.6 & 85 & 66. & 85.3 \\
\hline & $\begin{array}{l}\text { height of the first large branch } \\
(\mathrm{m})\end{array}$ & 3.9 & 3.7 & 7.7 & 10 \\
\hline & $\begin{array}{l}\text { height of the base of the crown } \\
(\mathrm{m})\end{array}$ & 3.1 & 3 & 8.5 & 10 \\
\hline & $\begin{array}{l}\text { average square diameter of the } \\
\text { crown }(m)\end{array}$ & 5.7 & 5.5 & 7.3 & - \\
\hline
\end{tabular}




\begin{tabular}{|c|c|c|c|c|c|c|c|c|c|c|}
\hline Station & Tree & \multirow{15}{*}{ dominant self-seeded tree } & Disc reference & Organ & Height (m) & Age & Radius under bark (cm) & Heartwood width $(\mathrm{cm})$ & Sapwood width $(\mathrm{cm})$ & Number of sapwood tree rings \\
\hline \multirow{14}{*}{ Bogny-sur-Meuse } & Bog. 0 & & 0a & trunk & 1 & 68 & 13.43 & 10.09 & 3.34 & 18 \\
\hline & Bog. 0 & & $0 \mathrm{~d}$ & trunk & 4 & 61 & 11.99 & 9.28 & 2.71 & 16 \\
\hline & Bog. 0 & & of & trunk & 6 & 52 & 11.41 & 8.86 & 2. 55 & 15 \\
\hline & Bog. 0 & & ohlb & branch & - & 45 & 5.44 & 3.61 & 1.83 & 26 \\
\hline & Bog. 0 & & 0hibla & branch & - & 43 & 4. 78 & 2. 35 & 2.43 & 29 \\
\hline & Bog. 0 & & Oh1blb & branch & - & 40 & 4. 06 & 0.00 & 4. 06 & 40 \\
\hline & Bog. 0 & & Ohlble & branch & - & 30 & 2.74 & 0.00 & 2.74 & 30 \\
\hline & Bog. 0 & & Ohld & branch & - & 39 & 4.44 & 2.52 & 1.92 & 22 \\
\hline & Bog. 0 & & Ohle & branch & - & 36 & 4. 49 & 2. 09 & 2.41 & 20 \\
\hline & Bog. 0 & & oh1f & branch & _- & 32 & 3. 75 & 0.00 & 3.75 & 32 \\
\hline & Bog. 0 & & 0m1a & branch & & 38 & 3.41 & 0.00 & 3.41 & 38 \\
\hline & Bog. 0 & & On & trunk & 14 & 36 & 4. 96 & 2.13 & 2.83 & 21 \\
\hline & Bog. 0 & & 0n2a & branch & & 33 & 2.68 & 0.00 & 2.68 & 33 \\
\hline & $\begin{array}{l}\text { Dog.0 } \\
\text { Bog. } 0\end{array}$ & & $0 \mathrm{n} 2 \mathrm{~b}$ & $\begin{array}{l}\text { branch } \\
\text { brand }\end{array}$ & - & $\begin{array}{l}50 \\
28\end{array}$ & 2.48 & 0.00 & $\begin{array}{l}2.00 \\
2.48\end{array}$ & 28 \\
\hline \multirow{23}{*}{ Cagouillères } & Cag. A & \multirow{23}{*}{ coppice trees } & A11A & trunk & 11 & 41 & 4.71 & 1.32 & 3. 39 & 34 \\
\hline & Cag. A & & A17A & trunk & 17 & 36 & 3. 29 & 0.00 & 3. 29 & 36 \\
\hline & Cag. A & & A $33 \mathrm{~A}$ & branch & & 26 & 1. 82 & 0.00 & 1.82 & 26 \\
\hline & Cag. B & & B10C & trunk & 10 & 36 & 5.42 & 2. 86 & 2. 56 & 23 \\
\hline & Cag. B & & B1A & trunk & 1 & 61 & 8.33 & 5.96 & 2.37 & 22 \\
\hline & Cag. B & & $\mathrm{B} 1 \mathrm{C}$ & trunk & 1 & 60 & 8.49 & 5.65 & 2.84 & 23 \\
\hline & Cag. B & & B2A & trunk & 2 & 58 & 7. 19 & 4. 72 & 2. 47 & 23 \\
\hline & Cag. B & & B3. C & trunk & 3 & 55 & 7. 02 & 4. 24 & 2. 79 & 24 \\
\hline & Cag. B & & B3A & trunk & 3 & 57 & 7. 18 & 4.57 & 2.61 & 24 \\
\hline & Cag. B & & B $48 \mathrm{~B}$ & branch & & 23 & 1.93 & 0.00 & 1.93 & 23 \\
\hline & Cag. C & & $\mathrm{C}^{2}$ & trunk & $\overline{2}$ & 60 & 6.08 & 3. 37 & 2.70 & 22 \\
\hline & Cag. C & & $\mathrm{C} 2 \mathrm{~B}$ & trunk & 2 & 60 & 6.25 & 4. 79 & 1. 46 & 23 \\
\hline & Cag. C & & C3A & trunk & 3 & 55 & 6.12 & 4. 62 & 1. 50 & 23 \\
\hline & Cag. C & & C48A & branch & - & 30 & 3.33 & 1.02 & 2.31 & 22 \\
\hline & Cag. C & & C51A & branch & - & 18 & 2.13 & 0.00 & 2.13 & 18 \\
\hline & Cag. C & & C52A & branch & - & 14 & 1.72 & 0.00 & 1.72 & 14 \\
\hline & Cag. C & & C5A & trunk & $\overline{5}$ & 46 & 5.60 & 4.03 & 1.57 & 22 \\
\hline & Cag. C & & $\mathrm{C8C}$ & trunk & 8 & 37 & 4. 98 & 3. 32 & 1.66 & 21 \\
\hline & Cag. D & & D10A & trunk & 10 & 48 & 6.28 & 3. 48 & 2.80 & 31 \\
\hline & Cag. D & & D13A & trunk & 13 & 38 & 3. 96 & 0.75 & 3. 21 & 29 \\
\hline & Cag. D & & D3C & trunk & 3 & 61 & 8.45 & 5.61 & 2.84 & 36 \\
\hline & Cag. D & & D47A & branch & - & 19 & 2. 49 & 0.00 & 2. 49 & 19 \\
\hline & Cag. D & & $\mathrm{D} 47 \mathrm{~B}$ & branch & & 20 & 2.89 & 0.00 & 2.89 & 20 \\
\hline
\end{tabular}




\begin{tabular}{|c|c|c|c|c|c|c|c|c|c|c|}
\hline \multirow{34}{*}{\begin{tabular}{|c} 
Station \\
Bois de 1' $1{ }^{\prime}$ or
\end{tabular}} & Tree & Regeneration & Disc reference & Organ & Height (m) & Age & Radius under bark (cm) & Heartwood width (cm) & Sapwood width (cm) & Number of sappood tree rings \\
\hline & & & & & & & 4.17 & & & 14 \\
\hline & Boi. 10 & & 10B. A & Trunk & 2 & 12 & 3.43 & 0 & 3. 43 & 12 \\
\hline & $\begin{array}{l}\text { Boi. } 10 \\
B \text { oi } 10\end{array}$ & & 10C. A & $\begin{array}{l}\text { Trunk } \\
\text { TTunk }\end{array}$ & 3 & ${ }_{9}^{11}$ & 2.84 & 0 & 2.84 & 11 \\
\hline & $\begin{array}{l}\begin{array}{l}\text { Boi. } 10 \\
\text { Boi. } 10\end{array} \\
\text { (n) }\end{array}$ & & 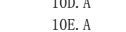 & & $\begin{array}{l}4 \\
5\end{array}$ & $\frac{9}{7}$ & $\begin{array}{l}2.62 \\
1.59\end{array}$ & $\begin{array}{l}0 \\
0\end{array}$ & $\begin{array}{l}2.62 \\
1.59\end{array}$ & $\begin{array}{l}9 \\
7\end{array}$ \\
\hline & 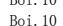 & & 10FA & $\begin{array}{l}\text { Trunk } \\
\text { Trunk } \\
\text { The }\end{array}$ & $\begin{array}{l}5 \\
6\end{array}$ & 5 & $\begin{array}{l}1.59 \\
0.92\end{array}$ & 0 & $\begin{array}{l}1,132 \\
0.92\end{array}$ & 5 \\
\hline & Boi. 13 & & $\begin{array}{l}10 . \mathrm{A} \\
13 \mathrm{~A}\end{array}$ & $\begin{array}{l}\text { Trunk } \\
\text { Trunk }\end{array}$ & 1 & 15 & 4.16 & 0 & 4.16 & 15 \\
\hline & Boi. 13 & & 13B. A & Trunk & 2 & 12 & 3.52 & 0 & 3.52 & 12 \\
\hline & Boi. 13 & & 13C. A & Trunk & 3 & 11 & 3.44 & 0 & 3. 44 & 11 \\
\hline & Boi. 13 & & & Trunk & 4 & 9 & 3.07 & & 3.07 & 9 \\
\hline & Boi. 13 & & 13E.A & Trunk & 5 & 8 & 2.27 & 0 & 2.27 & 8 \\
\hline & Boi. 13 & & 13F.A & Trunk & 6 & 6 & 1.96 & 0 & 1.96 & 6 \\
\hline & Boi. 13 & & 13G.A & Trunk & 7 & 4 & 2.75 & 0 & 2.75 & 4 \\
\hline & Boi. 13 & & 13G-1A B c & branch & & 6 & 1.33 & 0 & 1.33 & 6 \\
\hline & Boi. 14 & & $14 A . A$ & Trunk & 1 & ${ }_{14}$ & 4.19 & 0 & 4. 19 & 14 \\
\hline & $\begin{array}{l}\text { Boi. } 14 \\
B \text { Bi. } 14\end{array}$ & & 14B. A & $\begin{array}{l}\text { Trunk } \\
\text { TTumk }\end{array}$ & 2 & 11 & 3.60 & 0 & 3.60 & 11 \\
\hline & Boi.14 & & 14G.A A & Trunk & ${ }^{3}$ & 9 & 3.01 & 0 & 3.01 & 9 \\
\hline & $\begin{array}{l}\text { Boi. } 14 \\
\text { Boi } 14\end{array}$ & seeded trees & 14D. A & $\begin{array}{l}\text { Trunk } \\
\text { Trunk }\end{array}$ & 4 & 8 & $\begin{array}{l}2.82 \\
2.59\end{array}$ & $\begin{array}{l}0 \\
0\end{array}$ & $\begin{array}{l}2.82 \\
2.59\end{array}$ & 8 \\
\hline & $\begin{array}{l}\text { Bol.14 } \\
\text { Boi. } 14\end{array}$ & secened treess & $\begin{array}{l}14 . \mathrm{A} A \\
14 \mathrm{~F} . \mathrm{A}\end{array}$ & $\begin{array}{l}\text { Irunk } \\
\text { Trunk }\end{array}$ & 6 & $\frac{6}{7}$ & $\begin{array}{l}2.59 \\
2.60\end{array}$ & $\begin{array}{l}0 \\
0\end{array}$ & $\begin{array}{l}2.59 \\
2.60\end{array}$ & $\begin{array}{l}6 \\
7\end{array}$ \\
\hline & Boi. 14 & & $146 . \mathrm{A}$ & Trunk & 7 & ${ }_{4}$ & $\begin{array}{l}2.00 \\
1.44\end{array}$ & o & $\begin{array}{l}2.40 \\
1.44\end{array}$ & 4 \\
\hline & Boi. 14 & & $140-2 A B C$ & branch & & 8 & 1.56 & 0 & 1.56 & 8 \\
\hline & Boi. 17 & & 17A.A & Trunk & 1 & 14 & 4. 85 & 0 & 4.85 & 14 \\
\hline & Boi. 17 & & 177. A & Trunk & 2 & 12 & 2.97 & & 2.97 & 12 \\
\hline & Boi. 17 & & 177.A & Trunk & 3 & 11 & 2.85 & 0 & 2.85 & 11 \\
\hline & Boi. 17 & & 17D. A & Trunk & 4 & 9 & 2.43 & 0 & 2. 43 & 9 \\
\hline & $\begin{array}{l}\text { Boi. } 17 \\
\text { Boi. } 17\end{array}$ & & 17.E. A & $\begin{array}{l}\text { Trunk } \\
\text { hranch }\end{array}$ & 6 & 7 & $\begin{array}{l}1.49 \\
1.96\end{array}$ & $\begin{array}{l}0 \\
0\end{array}$ & $\begin{array}{l}1.49 \\
1.96\end{array}$ & ${ }_{8}^{7}$ \\
\hline & $\begin{array}{l}\text { Bol.17 } \\
\text { Boi. } 17\end{array}$ & & $\begin{array}{l}17 \mathrm{~A}-\mathrm{A} \\
17 \mathrm{~A}\end{array}$ & $\begin{array}{l}\text { Dranch } \\
\text { Trunk }\end{array}$ & $\overline{6}$ & $\frac{8}{5}$ & $\begin{array}{l}1.96 \\
1.32\end{array}$ & $\begin{array}{l}0 \\
0\end{array}$ & $\begin{array}{l}1.96 \\
1.32\end{array}$ & $\begin{array}{l}8 \\
5\end{array}$ \\
\hline & $\begin{array}{l}\text { Boi. } 17 \\
\text { Bon }\end{array}$ & & $\begin{array}{ll}176 . \mathrm{A} \\
176 . \mathrm{A}\end{array}$ & $\begin{array}{l}\text { Trunk } \\
\text { Trunk }\end{array}$ & 7 & 4 &  & 0 & $\begin{array}{l}1.82 \\
0.89\end{array}$ & ${ }_{4}^{4}$ \\
\hline & Boi. 19 & & 19A. A & Trunk & 1 & 13 & 4.29 & 0 & 4. 29 & 13 \\
\hline & Boi. 19 & & 19B. A & Trunk & 2 & 12 & 3.61 & 0 & 3.61 & 12 \\
\hline & Boi. 19 & & 19. A & $\begin{array}{l}\text { Trunk } \\
\text { Tumk }\end{array}$ & 3 & 9 & $\begin{array}{l}3.43 \\
0\end{array}$ & 0 & $\begin{array}{l}3.43 \\
0\end{array}$ & 9 \\
\hline & $\begin{array}{l}\text { Boi. } 19 \\
\end{array}$ & & 19D. A & $\begin{array}{l}\text { Trunk } \\
\text { Tonk }\end{array}$ & - & 8 & $\begin{array}{l}2.95 \\
200\end{array}$ & 0 & $\begin{array}{l}2.95 \\
2.97\end{array}$ & 8 \\
\hline & Boi. 19 & & 19. A $A$ & Trunk & 5 & $?$ & 2.22 & 0 & 2.22 & 7 \\
\hline & $\begin{array}{l}\text { Boi. } 19 \\
\text { Bo }\end{array}$ & & $\begin{array}{l}\text { 19F- A } \\
\text { 19c- }\end{array}$ & $\begin{array}{l}\text { Trunk } \\
\text { branch }\end{array}$ & 6 & $\begin{array}{l}5 \\
9\end{array}$ & $\begin{array}{l}1.62 \\
1.22\end{array}$ & 0 & 1.62 & 5 \\
\hline & Boi.11 & & 11. A A & Trunk & $\frac{t}{1}$ & 16 & $\frac{1.22}{4.72}$ & 0 & $\frac{1.22}{4.72}$ & $\frac{9}{16}$ \\
\hline & Boi. 11 & & 11B.A & Trunk & 2 & 14 & 3.55 & 0 & 3.55 & 14 \\
\hline & Boi. 11 & & 11C. A & Trunk & 3 & 12 & 3.52 & 0 & 3.52 & 12 \\
\hline & Boi. 11 & & 11D.A & Trunk & 4 & 10 & 2.91 & 0 & & 10 \\
\hline & Boi. 11 & & 11E. A & Trunk & 5 & 8 & 2.18 & 0 & 2. 18 & 8 \\
\hline & Boi. 11 & & 11F. A & $\begin{array}{l}\text { Trunk } \\
\text { Tonk }\end{array}$ & 6 & 6 & 1.70 & $0_{0}$ & $\begin{array}{l}1.70 \\
1.90\end{array}$ & 6 \\
\hline & $\begin{array}{l}\text { Boi.11 } \\
\text { Boi.11 }\end{array}$ & & $\begin{array}{r}116 . \mathrm{A} \\
11 \mathrm{E}-3 \mathrm{~A} \text {. }\end{array}$ & $\begin{array}{l}\text { Trunk } \\
\text { branch }\end{array}$ & 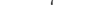 & $9_{9}^{4}$ & 年. & $\begin{array}{l}0 \\
0\end{array}$ & $\begin{array}{l}2.928 \\
1.48\end{array}$ & ${ }_{9}^{4}$ \\
\hline & Boi. 12 & & 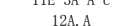 & Trint & $i$ & ${ }_{14}$ & 4.58 & 0 & 4.58 & 14 \\
\hline & Boi. 12 & & 12B. A & Trunk & 2 & 14 & 4. 10 & 0 & 4. 10 & 14 \\
\hline & Boi. 12 & & 12C. A & Trunk & 3 & 12 & 3.91 & 0 & 3.91 & 12 \\
\hline & Boi. 12 & & 12D. A & Trunk & 4 & 10 & 3.41 & 0 & 3.41 & 10 \\
\hline & $\begin{array}{l}\text { Boi. } 12 \\
\text { Boin } 12\end{array}$ & & $\begin{array}{l}\text { 12E. A } \\
\text { 12. A }\end{array}$ & $\begin{array}{l}\text { Trunk } \\
\text { Trumk }\end{array}$ & 5 & $\begin{array}{l}8 \\
6\end{array}$ & $\begin{array}{l}3.61 \\
2.28\end{array}$ & $\begin{array}{l}0 \\
0\end{array}$ & $\begin{array}{l}3.61 \\
2.28 \\
28\end{array}$ & 8 \\
\hline & $\begin{array}{l}\text { Boi. } 12 \\
\text { Boit }\end{array}$ & & $\begin{array}{l}12 . \mathrm{A} A \\
12 \mathrm{~A}\end{array}$ & $\begin{array}{l}\text { Trunk } \\
\text { Trunk }\end{array}$ & $\begin{array}{l}6 \\
7\end{array}$ & $\begin{array}{l}6 \\
5\end{array}$ & $\begin{array}{l}2.28 \\
1.23\end{array}$ & 0 & $\begin{array}{l}2.28 \\
1.23\end{array}$ & $\begin{array}{l}6 \\
5\end{array}$ \\
\hline & 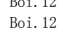 & & $\begin{array}{l}12 \mathrm{~B} \cdot \mathrm{A} \\
12 \mathrm{~A}\end{array}$ & $\begin{array}{l}\text { Irunk } \\
\text { Trunk }\end{array}$ & 8 & $\begin{array}{l}5 \\
4\end{array}$ & $\begin{array}{l}1.23 \\
0.85\end{array}$ & 0 & $\begin{array}{l}1.23 \\
0.85\end{array}$ & $\begin{array}{l}5 \\
4\end{array}$ \\
\hline & Boi. 12 & & $12 \mathrm{E}-1 \mathrm{~A} \mathrm{D} \mathrm{c}$ & $\begin{array}{l}\text { branch } \\
\text { bran }\end{array}$ & & $\begin{array}{l}7 \\
9\end{array}$ & 1.30 & 0 & 1.30 & $\begin{array}{l}7 \\
9\end{array}$ \\
\hline & Boi. 15 & & 15A. A & Trunk & 1 & 14 & 3.99 & 0 & 3.99 & 14 \\
\hline & Boi. 15 & & 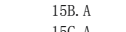 & Trunk & 2 & 12 & 3.49 & 0 & $\begin{array}{l}3.49 \\
3\end{array}$ & 12 \\
\hline & $\begin{array}{l}\text { Boi. } 15 \\
\text { Boi } 15\end{array}$ & coppice trees & $\begin{array}{l}15 \mathrm{C} \text {. A } \\
15 \mathrm{D}\end{array}$ & $\begin{array}{l}\text { Trunk } \\
\text { Trunk }\end{array}$ & $\begin{array}{l}3 \\
4\end{array}$ & ${ }_{8}^{11}$ & $\begin{array}{l}3.15 \\
1.87\end{array}$ & $\begin{array}{l}0 \\
0\end{array}$ & $\begin{array}{l}3.15 \\
1.87\end{array}$ & $\begin{array}{l}11 \\
8\end{array}$ \\
\hline & 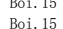 & & $\begin{array}{l}\text { 1515. A } \\
15 \mathrm{E} \text {. }\end{array}$ & $\begin{array}{l}\text { Trunk } \\
\text { Trunk }\end{array}$ & $\begin{array}{l}4 \\
5\end{array}$ & $\begin{array}{l}8 \\
6\end{array}$ & $\begin{array}{l}1.87 \\
1.30\end{array}$ & $\begin{array}{l}0 \\
0\end{array}$ & $\begin{array}{l}1.87 \\
1.30\end{array}$ & ${ }_{6}^{6}$ \\
\hline & Boi. 15 & & $\begin{array}{l}\text { 15.A.A } \\
\text { 15. }\end{array}$ & Trunk & 6 & ${ }_{4}$ & 0.84 & 0 & 0.84 & 4 \\
\hline & Boi. 15 & & $15 \mathrm{D}-1 \mathrm{~A}$ & branch & & 8 & 1.66 & 0 & 1.66 & 8 \\
\hline & Boi. 16 & & 16A. A & Trunk & 1 & ${ }^{14}$ & 4.36 & 0 & 4. 36 & 14 \\
\hline & Boi. 16 & & 16B. A & $\begin{array}{l}\text { Trunk } \\
\text { Tumk }\end{array}$ & 2 & ${ }_{13}^{13}$ & $\begin{array}{l}3.94 \\
3\end{array}$ & 0 & $\begin{array}{l}3.94 \\
3.56\end{array}$ & 13 \\
\hline & $\begin{array}{l}\text { Boi. } 16 \\
\text { nai }\end{array}$ & & $\begin{array}{l}16 \mathrm{CD} A \\
{ }_{16} \mathrm{~A} \mathrm{~A}\end{array}$ & $\begin{array}{l}\text { Trunk } \\
\text { Trunk }\end{array}$ & $\begin{array}{l}3 \\
4 \\
4\end{array}$ & ${ }_{9}^{12}$ & $\begin{array}{l}3.56 \\
3.14 \\
3.14\end{array}$ & $\begin{array}{l}0 \\
0 \\
0\end{array}$ & $\begin{array}{l}3.56 \\
3.14\end{array}$ & ${ }_{9}^{12}$ \\
\hline & 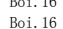 & & $\begin{array}{l}1016 . \mathrm{A} \\
16 \mathrm{E} . \mathrm{A}\end{array}$ & $\begin{array}{l}\text { Irunk } \\
\text { Trunk }\end{array}$ & 5 & ${ }_{13}$ & $\begin{array}{l}3.14 \\
3.69\end{array}$ & 0 & $\begin{array}{l}3.14 \\
3.69 \\
3\end{array}$ & 13 \\
\hline & Boi. 16 & & 16F.A & Trunk & 6 & 11 & 2.80 & 0 & 2.80 & 11 \\
\hline & Boi. 16 & & 16G. A & Trunk & 7 & 4 & 1. 10 & 0 & 1. 10 & 4 \\
\hline & Boi. 16 & & 16E- $3 \mathrm{~A}$ & branch & & 8 & 1.14 & 0 & 1.1 14 & 8 \\
\hline & Boi. 18 & & 18A. A & Trunk & 1 & 13 & $\begin{array}{l}4.05 \\
4\end{array}$ & 0 & $\begin{array}{l}4.05 \\
4.25\end{array}$ & 13 \\
\hline & $\begin{array}{l}\text { Boi. } 18 \\
\text { Boit }\end{array}$ & & $\begin{array}{l}18 B \mathrm{~B} \text {. A } \\
18 \mathrm{CA}\end{array}$ & $\begin{array}{l}\text { Trunk } \\
\text { Trunk }\end{array}$ & $\begin{array}{l}2 \\
3 \\
3\end{array}$ & ${ }^{12}$ & $\begin{array}{l}4.25 \\
3.34\end{array}$ & 0 & $\begin{array}{l}4.25 \\
3.34\end{array}$ & 112 \\
\hline & $\begin{array}{l}\text { Doi. } 18 \\
\text { Boi. }\end{array}$ & & $\begin{array}{l}18 . \mathrm{A} \\
18 \mathrm{~A} . \mathrm{A}\end{array}$ & $\begin{array}{l}\text { Irunk } \\
\text { Trunk }\end{array}$ & 4 & $\begin{array}{l}11 \\
10\end{array}$ & $\begin{array}{l}3.34 \\
3.09\end{array}$ & 0 & $\begin{array}{l}5.344 \\
3.09\end{array}$ & $\begin{array}{l}11 \\
10\end{array}$ \\
\hline & Boi.18 & & 18E. A & Trunk & 5 & 8 & 2.13 & 0 & 2. 13 & 8 \\
\hline & Boi. 18 & & $18 \mathrm{E}-3 \mathrm{~A}$ & branch & & 8 & 1.82 & 0 & 1.82 & 8 \\
\hline & 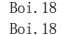 & & $\begin{array}{l}\text { 18F. A } \\
18 . \mathrm{A}\end{array}$ & $\begin{array}{l}\text { Trunk } \\
\text { Trunk }\end{array}$ & ${ }_{7}^{6}$ & $\begin{array}{l}6 \\
5 \\
5\end{array}$ & $\begin{array}{l}1.34 \\
1.17\end{array}$ & $\begin{array}{l}0 \\
0\end{array}$ & $\begin{array}{l}1.34 \\
1.17\end{array}$ & 6 \\
\hline
\end{tabular}

